\title{
Climate-Driven Change of the Stand Age Structure in the Polar Ural Mountains
}

\author{
Valeriy Mazepa, Stepan Shiyatov and Nadezhda Devi \\ Institute of Plant and Animal Ecology, Ural Branch Russian Academy of Sciences \\ Russia
}

\section{Introduction}

Most records across the Arctic show a widespread transition from cold conditions of the $19^{\text {th }}$ century to warm conditions of the $20^{\text {th }}$ century, with local warming of $1-3^{\circ} \mathrm{C}$ that average $\sim 1.5^{\circ} \mathrm{C}$ across the Arctic domain (Jackson et al., 1997). The region has experienced higher warming rates over the last 30 years and the process has been accelerating at unprecedented rates over the last decade (Miller et al., 2010). The mean global temperatures of the last decade have been the warmest for the last 1000 years, and projections suggest a further increase in the average surface temperature around the world (Briffa et al., 1995; Esper \& Schweingruber, 2004; IPCC, 2007). In the arctic and alpine regions, the estimated temperature anomalies for the past 100 years were twice as large as those averaged for the northern hemisphere (Kelly et al., 1982). Warming is expected to have large effects on global vegetation and plant distribution, particularly in ecosystems at high altitudes and high latitudes, where plant growth is mainly limited by temperature (Kittel et al., 2000; Becker \& Bugmann, 2001; Shiyatov \& Mazepa, 2007).

Today, spatiotemporal studies of forest-tundra and forest-grassland plant communities in high mountains are given considerable but deserved consideration because of the opportunity and necessity to evaluate their responses to what is widely considered to be anomalous $20^{\text {th }}$ century warming (Kullman, 1990; Körner, 1999; Holtmeier, 2003). The montane plant communities growing at high latitudes are of particular interest because of the magnitude of climate change observed in instrumental records at these locations (Briffa \& Jones, 1993). The pace and pattern of biotic response to climate variation on scales of decades to centuries is highly relevant to understanding the potential ecological consequences of anthropogenically induced climate change (Lloyd, 1997). Conducting such research in "natural" or largely undisturbed areas where human impact is minimal is highly desirable.

Patterns of plant population response to climate variation are most clearly observed at climatically determined ecotones, where the abiotic environment is the ultimate control over ecological processes (Lloyd \& Graumlich, 1997). Following Körner (1999), the term "tree-line ecotone" is taken here to represent the transitional belt of mountain vegetation situated between the upper limit of single tree growth in the tundra and the upper limit of closed forests. This ecotone is wider than the subgoltsy belt, because it covers the lower part of the mountain tundra belt, where solitary woody plants are found. 
In the Polar Urals, dead trees at high elevation are preserved in situ for more than a millennium. Numerous explorers (Sukachev, 1922; Gorodkov, 1926; Sochava, 1927; Andreev et al., 1935) observed a great number of dead trees and wood remains in various degrees of decomposition around the upper tree-line on the eastern slope of the Polar Ural Mountains. Such wood is especially abundant in the Sob River Basin. Dead trees located above the current tree-line ecotone provide evidence of the spatio-temporal dynamics of the forest-tundra communities in the recent past. The paleoecological record preserved in these dead trees is highly resolved, both spatially and temporally, providing a unique opportunity to reconstruct the precise history of actual changes in the structure of foresttundra stands (Shiyatov, 1993, 2003; Mazepa, 2005).

Historic photographs as well as satellite remote sensing surveys documented that highlatitude ecosystems have changed considerably during the last century: in tundra regions of northern Alaska and central Russia, the abundance of shrubs has increased strongly (Myneni et al., 1997; Shvartsman et al., 1999; Silapaswan et al., 2001; Sturm et al., 2005), and tree-line as well as forest-tundra ecotones in North America, Scandinavia, Siberia, and Urals have been shifting north- and upwards (Kullman, 2002; Kharuk et al., 2002; Shiyatov, 2003; Moiseev \& Shiyatov, 2003; Esper \& Schweingruber, 2004; Shiyatov, 2009). Similarly, dendroecological studies show that trees at high latitudes and altitudes of the northern hemisphere have been growing better during the last decades (Paulsen et al., 2000). There are, however, also reports on decreasing tree growth in the drier regions of Interior Alaska (D’Arrigo et al., 2004) and Middle Siberia (Vaganov et al., 1999). In contrast to the growth of individual trees, little is known about the impact of climatic changes on the growth forms and growth strategies of trees. At the fringe of their distribution, boreal trees grow in a number of growth forms (creeping, single-, and multistem), and they are able to adapt their growth form to environmental changes (Gorchakovskiy \& Shiyatov, 1985; Weisberg \& Baker, 1995; Pereg \& Payette, 1998; Goroshkevich \& Kustova, 2002; Holtmeier, 2003; Mazepa \& Devi, 2007; Devi et al., 2008). However, there is no quantitative understanding on the development and the timing of these growth forms, and to date only few attempts have been made to link the dynamics of growth forms to the changes in climatic conditions.

Forest expansions into former tundra could induce positive and negative feedbacks of ecosystems with climate (Chapin et al., 2000). While increasing tree biomass sequesters carbon from the atmosphere and thus would lead to a negative feedback, decreasing albedo through increasing tree cover would amplify atmospheric heating, particularly during the snow-covered season. For arctic Alaska, Chapin et al. (2005) estimated that the potential heating effect by expanding forests exceeds the climatic effects induced by a doubling of atmospheric $\mathrm{CO}_{2}$. However, treeline advances and forest establishment lag behind anthropogenic climatic change, and rates of change differ strongly among sites, which add great uncertainties in predicting the feedbacks between terrestrial ecosystems and climate (Lloyd, 2005).

One such promising area is the Polar Ural Mountains. Important note has to be made with respect to the choice of the field site location. The eastern macroslope of the Polar Urals represents a pristine environment where tundra, forest, and shrub ecosystems have not been exposed to significant anthropogenic impact and show no signs of forest fires in more than 1000-year long tree-ring records (Shiyatov, 1965, 1986, 2003; Mazepa, 2005). These ecosystems experience the effect of natural disturbance factors; these are mainly related to climate variability/change. Furthermore, the routes of seasonal migration of reindeer herders go 
around this area because of the danger related to crossing of the Sob River and the railroad. Most backpackers, who travel to the Rai-Iz range, approach it from the western and northern slopes because of the proximity to railroad stations. From the eastern side, it is only possible to reach the foothills of the mountains using an all-terrain vehicle. Consequently, the proposed field monitoring area represents an ideally suited location for studies of climate impacts on pristine tundra, forest, and forest-tundra communities of the subarctic region.

This paper demonstrates how the age structure of forest-tundra stands within the former and current tree-line ecotone and the morphogenesis of Siberian larch in the Polar Urals have changed over the last millennium.

\section{Materials and methods}

\subsection{Study area}

The study area is located on the eastern slope of the Polar Ural Mountains, in the Sob River basin $\left(66^{\circ} 46^{\prime}-66^{\circ} 55^{\prime} \mathrm{N}, 65^{\circ} 22^{\prime}-65^{\circ} 49^{\prime} \mathrm{E}\right), 50 \mathrm{~km}$ northwest of the Ob River and $30 \mathrm{~km}$ north of the Arctic Circle (Fig. 1). The bedrock basically consists of Paleozoic amphibolite and crystal granodiorite, which forms a series of peaks and depressions 1000-1200 m a.s.l. There are over 90 glaciers in the Polar Ural Mountains. Recent publications indicate a reduction in the volume of these mountain glaciers (Solomina, 1999), almost all of which are located in deep depressions and valleys on east- and north-facing slopes, on the leeward side of the mountains. They are classified as so-called hillside and kar glaciers and located below the snow line. This is possible because the snow is distributed by the wind and concentrated in depressions, which allows the glaciers to survive. Traces of glacial activity (i.e., lateral moraines and lakes of a glacial origin) are visible, and dating studies of the moraines have been reported by Yu. Martin (1970).

In the current study, meteorological data recorded at Salekhard meteorological stations (Fig. 1) have been used. Salekhard station is located $55 \mathrm{~km}$ southeast of the study area in the valley of the $\mathrm{Ob}$ River at an elevation of $35 \mathrm{~m}$ a.s.l. The record begins in 1883 .

The mean annual air temperature for Salekhard station is about $-6.7^{\circ} \mathrm{C}$; mean monthly minimum (January) and maximum (July) temperatures are about -24.4 and $13.8{ }^{\circ} \mathrm{C}$, respectively. The mean frost-free period lasts about 64 days, and the growing season extends from mid-June to early August. Frosts are possible in all summer months, and short-duration positive temperatures can be experienced in all winter months. The mean annual precipitation is $500-600 \mathrm{~mm}$, with $50 \%$ falling as snow.

The annual radiation balance is positive and about $42 \mathrm{~J} / \mathrm{cm}^{2}$. The study area is in a zone of continuous permafrost. The Polar Urals are influenced by a predominantly westerly air flow, with minimum wind speed observed in summer (average 5-6 m/s) and maximum in winter (average 9-10 m/s). Peak registered wind speeds can reach $40-50 \mathrm{~m} / \mathrm{s}$, a characteristic feature of west-east oriented valleys.

The study area is located within the tree-line ecotone and occupies deep valleys and lower slopes up to 200-350 m a.s.l. Within the tree-line ecotone (with occasional single trees found at $400-410 \mathrm{~m}$ a.s.1.) Siberian larch (Larix sibirica Ledeb.) stands of varying density predominate. These are found in association with Siberian spruce (Picea obovata Ledeb.) and mountain birch (Betula tortuosa Ledeb.). Patches of closed larch-spruce forests grow at lower elevations. There are also dense stands of tall shrubs (Dushekia fruticosa (Rupr.) Pouzar) and some species of Salix (Salix lanata L., Salix philicifolia L.). 


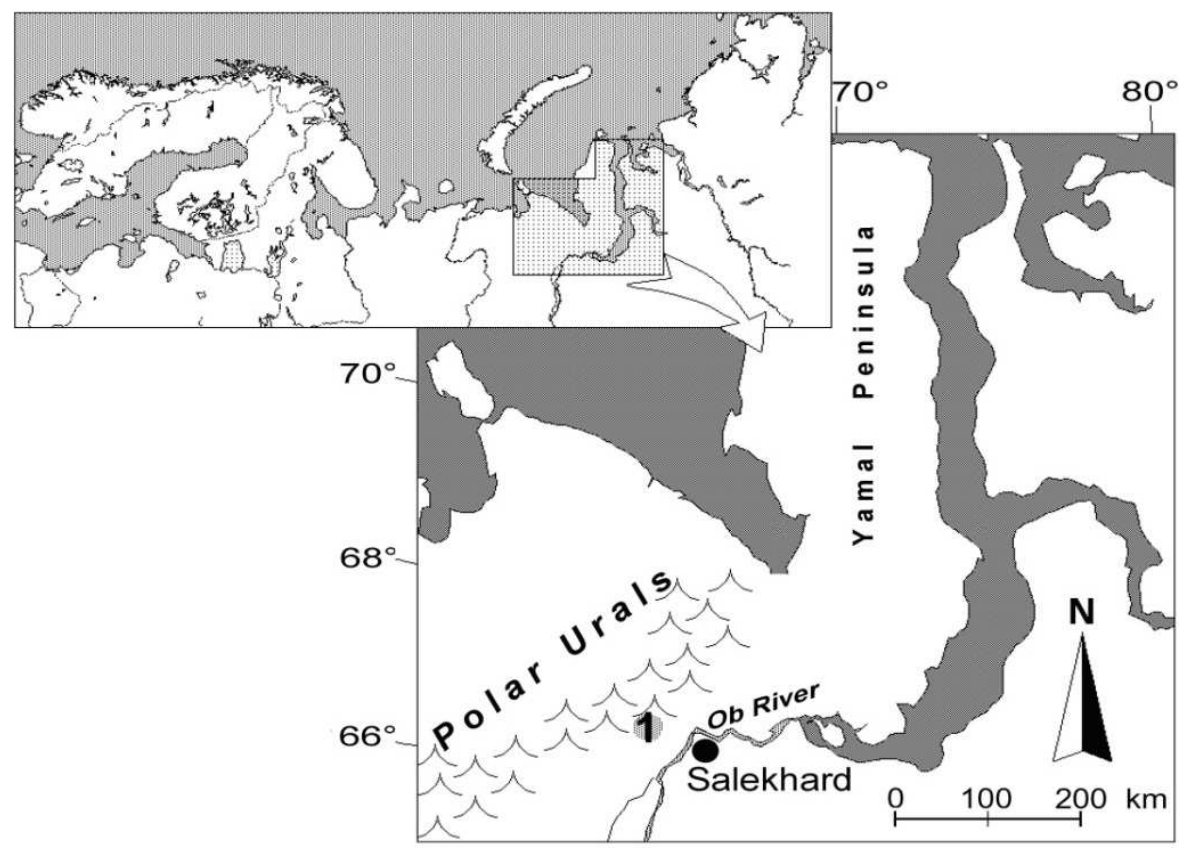

Fig. 1. Location of the study area (1) in the Polar Urals.

Larch growth and morphology is influenced by wind conditions and the effects of major snowdrifts (Fig. 2), which cause structural deviation from the arborescent, monopodial growth form and the development of stem anomalies (matgrowth, wedge, hedge, cornice, flag table tree, multi-stemmed growth forms).
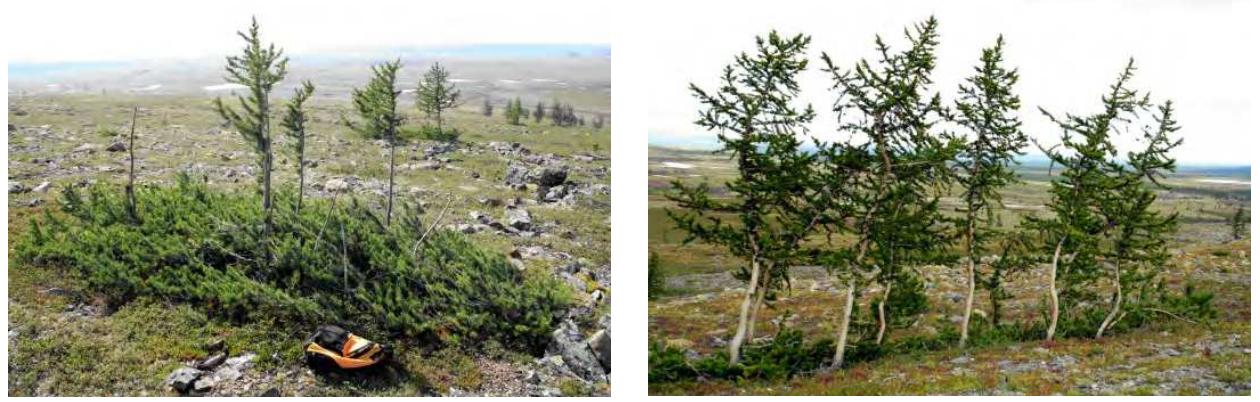

Fig. 2. Different life growth forms of larch trees under wind and snowdrift conditions.

A great number of wood remnants on the ground, up to $60-80 \mathrm{~m}$ above the present tree-line ecotone, provide direct evidence of forest-tundra ecosystem changes. These remnants have been preserved for a long time, up to 1500 years, because of the low rate of wood decomposition in these severe climatic conditions (Fig. 3). These circumstances provide us with the possibility of extending the local tree-ring chronology back to AD 459, while at the same time accurately dating the life-spans of a large number of the living and dead trees. 


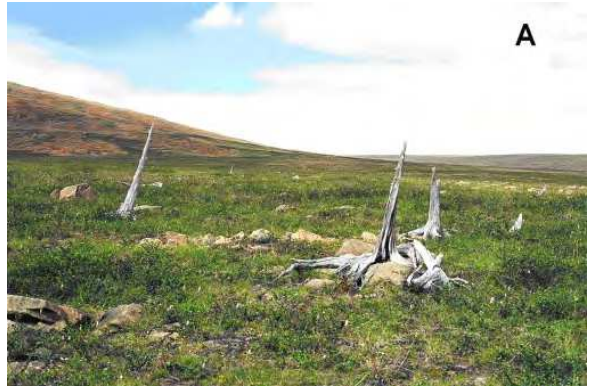

Fig. 3. Remnants of the larch trees which have died off during at the beginning (A) and the end of Little Ice Age (B).

\subsection{Field sampling}

As the experimental field framework we used altitudinal profiles/transects, laid out previously. Field data on forest stands were obtained by using 6 permanent, continuous altitudinal transects $300-1100 \mathrm{~m}$ long and $20-80 \mathrm{~m}$ wide. These transects were divided into squares of $20 \mathrm{~m} \times 20 \mathrm{~m}$ length-wise and delineated by stone piles in grid corners. On one side of each transect, stone piles were numbered. The locations of all live trees, standing dead trees, and fallen dead trees as well as woody remnants were mapped. Transects typically begin at the upper tree-line of the past, where both live trees and tree remnants cannot be anymore found. The other part of all transects is located in the modern tree-line ecotone and begins in the area of sparse tree growth and open forests, extending further down slope to closed-canopy forest. Transect elevation range is approximately $220-250 \mathrm{~m}$.

From each tree samples were collected for a dendrochronological estimation of their calendar life span and age. On each transect all dead trees and wood remnants were mapped and cross-sections were taken for tree-ring dating of life span. 2262 cross-sections in total from preserved remnants of dead trees were collected. The degree of decay (presence of sapwood, extent of center rot) was noted for all samples. Each specimen was examined prior to cutting to select the radius most likely to contain the maximum number of rings. Not all wood remnants on the altitudinal transect were suitable for dendrochronological analysis because of a high degree of decay, especially in the lower part of transects, where these remnants are found under moss cover. The total number of cross-sections obtained represented $>90 \%$ of all wood remnants mapped. For approximately half of these remnants, samples were taken from ground-level stump remnants (virtually the upper root) because of the poor preservation of the stem wood.

In order to determine when multi-stemmed trees changed from creeping to upright growth, we cut disks of 23 tree clusters with 2-27 stems in cluster. Cross-sections were taken at the base of their horizontal creeping stems and again at the base of the vertical stem (Fig. 4).

Biomass of each growth form was estimated using selected 34 representative plants (21 single-stemmed, 10 multi-stemmed and 3 creeping). These trees were dug out including the full rooting system (except fine roots). Different compartments of biomass such as roots, stems, branches, needles, and cones were counted, measured, weighted, and sub-samples were taken to the laboratory to dry them at $106^{\circ} \mathrm{C}$. 


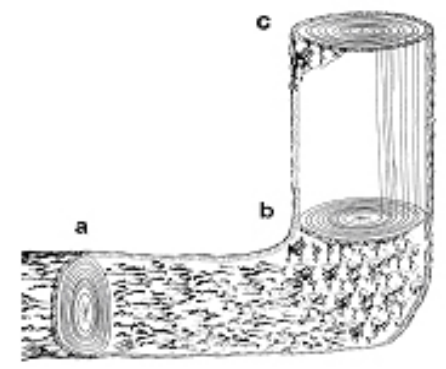

Fig. 4. Three places of wood sampling to determine linear growth rate and the dates when multi-stemmed trees have changed from creeping to upright growth.

\subsection{Methods}

The main source of information for the spatio-temporal reconstruction of stand structure in response to climate change was the observational record of the long-term monitoring program (about 50 years) in the studied area. The monitoring has been conducted using different methods, including tree taxation, cartographic, photographic and dendrochronological methods.

Forest taxation method includes measuring the main morphometric parameters of all standing trees and newly grown tree seedlings along pre-determined permanent altitudinal profiles/transects. The most reliable method of the tree cover change assessment in time and space is the identification of age structure of living and dead tree stands as well as tree remnants. These methodologies have been previously successfully tested in conditions of the Polar Urals (Shiyatov, Mazepa, 2007).

In order to evaluate the productivity of tree stands, the method of "representative plants" was used. Both aboveground and below-ground dry biomass was determined. Various compartments were represented: bark and sapwood of tree branches, stems, and roots as well as foliage and reproductive organs. The biomass of each plot within the transects was then estimated by calculating allometric function between tree diameter or sectional areas and the measured compartment biomasses, followed by multiplying these amounts with the mapped tree diameters (Fig. 5). Carbon storage in the biomass was calculated by multiplying biomass with 0.5 (Kobak, 1988).

We also made repeated large-scale ecosystem mapping in key areas of the field site to estimate horizontal and vertical shifts of the upper tree-line of various types of forest-tundra and forest communities using GIS technology. A new technique for estimating the shifts of the upper boundary of open and closed forest communities has been developed and tested using highland areas of the Polar Urals as a case study. The technique is based on estimation and GIS representation of boundaries at the beginning and end of the analysis period (Shiyatov et al., 2007).

The photographic technique is the method of taking repeated landscape photos from the same locations where historical photos had been taken. This provides valuable information on changes in structure and spatial locations of woody and shrubby vegetation over the past 80-100 years. High-mountainous areas with open views of landscape are ideally suited for using this technique: previous locations of photography can be easily determined using characteristic points on topographic maps for geolocation. The proposed site exhibits all necessary characteristics for using this method. Repeated photos had been taken here 
previously at each of such locations; the exact geographic coordinates were determined using accurate GPS-receivers.
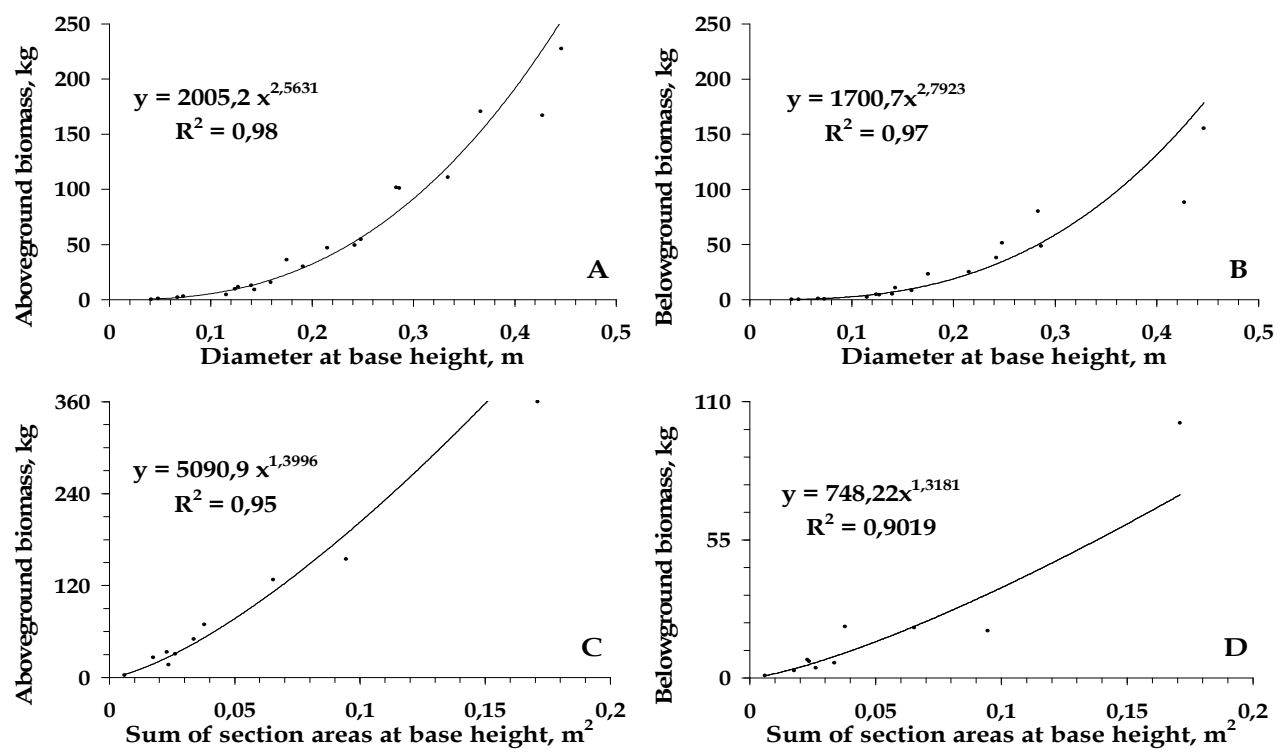

Fig. 5. Tree diameter (or sum of section areas), above- and belowground biomass relationships for single-stemmed (A and B) and multiple-stemmed trees (C and D).

\subsubsection{Tree-ring methods}

A particular attention was given to the dendrochronological method. Specifically, on the basis of tree-ring analysis, biological age and calendar life span of each individual tree can be estimated. The use of this technique in conditions of the Polar Urals, where remnants of dead trees remain intact over long periods of time (up to 1.5 thousand years), is especially promising. The method is also suitable because the correlation of the radial growth among trees over a huge area is very high from year to year.

We used this technique in the study area for a reconstruction of mean summer (June-July) air temperature of the past. A high reliability of the tree-ring reconstruction method in conditions of the Far North is achievable because of high correlations between tree-ring indexes and corresponding climatic factors. The theoretical basis and methods that was used for the reconstruction of climatic conditions of the past have been described in a monograph (Vaganov et al., 1996).

To determine the calendar year of each inner and outer ring, ring widths in each crosssection were measured and cross-dated against existing larch chronologies from the Polar Urals. Cross-dating enabled the assignment of a calendar year to each annual ring. This was accomplished by visually comparing dated and undated samples. A computer program, COFECHA (Holmes 1995), which statistically matches undated samples against samples for which exact dating has been established, was also used to confirm the dating.

Inner and outer ring dates for each cross-section established in this way do not represent the exact germination and mortality dates of the trees because of pre- and post-mortem decay of 
the wood. The innermost wood in many dead trees was also found to have decayed. For the altitudinal transect-1, laid out within the current tree-line ecotone, we made a detailed analysis for accuracy determination of exact germination and mortality dates of the trees (Fig. 6). It proved possible to cross-date 667 series from the 769 samples collected within the transect-1. The remaining 102 samples had too few rings (from 17 to 43 ).

A total of 85 cross-sections (average age $171 \pm 78$ years, \pm l SE) had both inner and outer rings (bark rings). The life-span of these trees lasted until the 17th to $19^{\text {th }}$ century (Fig. 6A and 6B), whereas 359 cross-sections (average age $147 \pm 60$ years) had inner rings only. Germination dates are bimodally distributed (Fig. 6C). Cross-sections from 16 trees (average age $138 \pm 55$ years) had outer rings (bark rings) only. Death dates are concentrated in the $19^{\text {th }}$ century (Fig. 6D). The remaining 207 cross-sections (average age $118 \pm 53$ years) had neither inner nor outer rings.
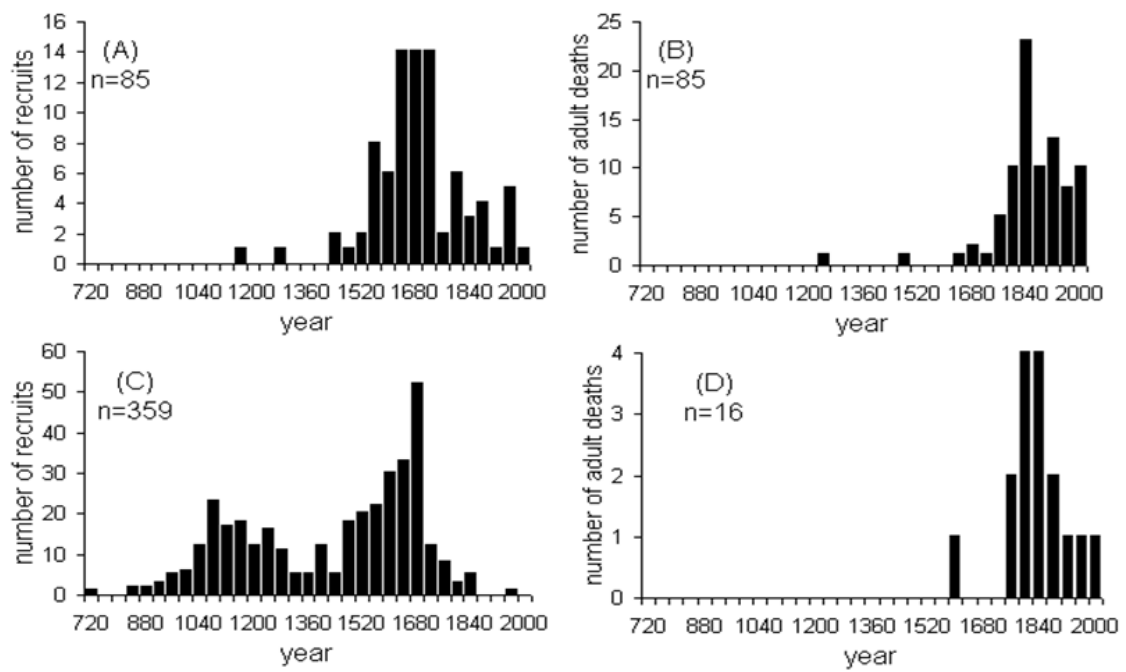

Fig. 6. The life-spans of sampled dead trees, which had both inner (A) and outer rings (B), inner rings only $(C)$, and outer rings only (D).

For most cross-sections with no inner rings surviving, it was generally possible to measure the distance from the innermost measurable ring to the estimated pith position of the crosssection and estimate the number of missing rings using a circle template fit to the ring curvature. The estimate took into account the mean ring width for at least 10 years for the appropriate tree age and time period.

To estimate true establishment date, it is also necessary to account for the relationship between the true ages of living trees (established from hypocotyls) and the ages of the full cross-sections. This relationship was derived on the basis of measurements made on 21 selected trees growing near the transect-1. These trees were dug out of the ground to enable estimates of the biomass to be measured. The trees were ranked by basal diameter and height from $4 \mathrm{~cm}$ up to $45 \mathrm{~cm}$ and from $2 \mathrm{~m}$ up to $13 \mathrm{~m}$, respectively. Sections were also cut from stems, at a height of $20-25 \mathrm{~cm}, 1.3 \mathrm{~m}$, and every $1 \mathrm{~m}$ above the position of the hypocotyls. The dates of the innermost ring on each cross-section were determined. On average, the 9- to 14 - year-old trees are $20-25 \mathrm{~cm}$ high and the 28 - to 43 -year-old trees are 1.3 
$\mathrm{m}$ high. This relationship was used to estimate the establishment date of those trees surviving only as subfossils.

Because of postmortem decay and erosion of outer-surface wood, the outer ring date of these samples is in most cases not the true mortality date. In general, it was not possible to establish the "true" mortality date with great confidence; however, in some cases a closer estimate could be produced by using additional sections from the same remnants, but taken from different parts of the stumps.

\section{Results}

\subsection{Stand age structure since AD 1500}

The analysis of 2 altitudinal transects within the current tree-line ecotone has shown that the locations of the dead and living dated larch trees was not uniform (Fig. 7).

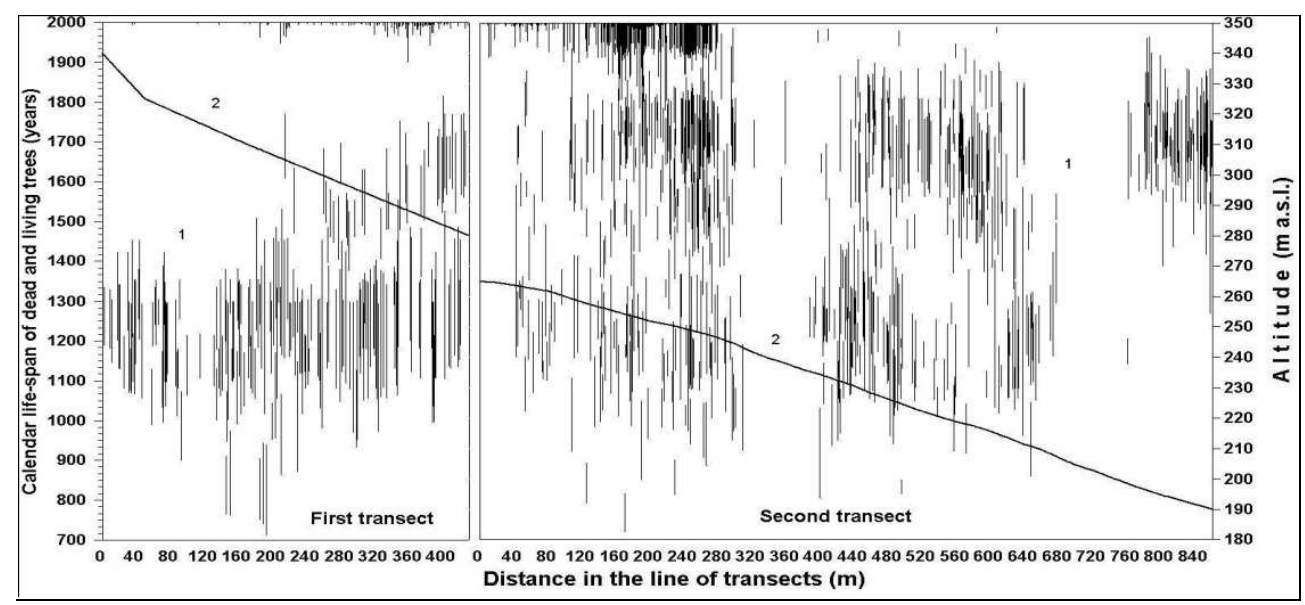

Fig. 7. Location of the dated larch remnants and living trees along transects and their lifespan. Time of appearance of living trees in the bottom part transect- 2 is not shown: (1) life span of trees; (2) altitude changing of transects.

The overwhelming majority of remnants occur within three parts of the second transect. The first forest island became established between $30-40 \mathrm{~m}$ and $300-320 \mathrm{~m}$ in distance, along transect. The second stand is situated from between 380-400 $\mathrm{m}$ and 640-660 $\mathrm{m}$ further down. The third stand occupies an area from 750-770 $\mathrm{m}$ up to the end of transect. Live trees grow in the same parts of transects. Such a spatial distribution of trees is caused by the particular micro relief in different parts of transects. The higher part of transect is almost at the uppermost point of the moraine. Here, there are no barriers from wind, and this site is similar to a wind-dominated ecological type of tree-line. At a distance of about $320 \mathrm{~m}$ from the beginning of transect- 1 , there is a slope that is formed by stone ledges. Here, during wintertime, increased snowdrifts up to 3-6 m in height accumulate. Such a significant depth of snow and the associated delay in the spring thaw that results from it are unfavorable factors for the survival of undergrowth. Absence of forest stands in these parts of transect is, therefore, caused by high snow depths in the wintertime. The same micro relief is found at a distance of about $680 \mathrm{~m}$ from the top of transect. 
Wood macrofossils from the bottom part of the transect date mainly to the $16^{\text {th }}$ to $19^{\text {th }}$ centuries. On this site the more ancient remnants have not, in general, been preserved. The reason is that this part of transect is a closed forest stand with mature moss cover. Such conditions lead to increased decomposition of wood. The greatest number of undated samples was found in this part of transect, and their poor state of preservation meant that many samples could not be taken at all.

Using the calendar life-spans of the dead, changes in abundance through time were estimated by calculating the number of trees that were alive during each of the years from 1300 years ago to the present. Abundance estimates are subject to two specific errors. First, the sample is biased toward larger trees. Saplings and small adult trees are likely to decompose more rapidly than large trees, resulting in their systematic exclusion from the sample. Second, the record deteriorates back in time because of the decomposition of all wood. The sample therefore includes an increasing proportion of the original forest composition in more recent periods and would be expected, as a result of decomposition alone, to indicate a trend of increasing tree abundance with time. Although trees have been dated as far back as AD 720, the analysis has been truncated at AD 1000 to minimize the influence of the diminishing record (Fig. 8). An early peak of abundance is observed from the end of the $12^{\text {th }}$ century to the second half of the 13th century. For this time interval the average stand density is estimated at 50-60 trees/ha. A correction was made in the observed tree abundance at the end of the $12^{\text {th }}$ century and the second half of the $13^{\text {th }}$ century.

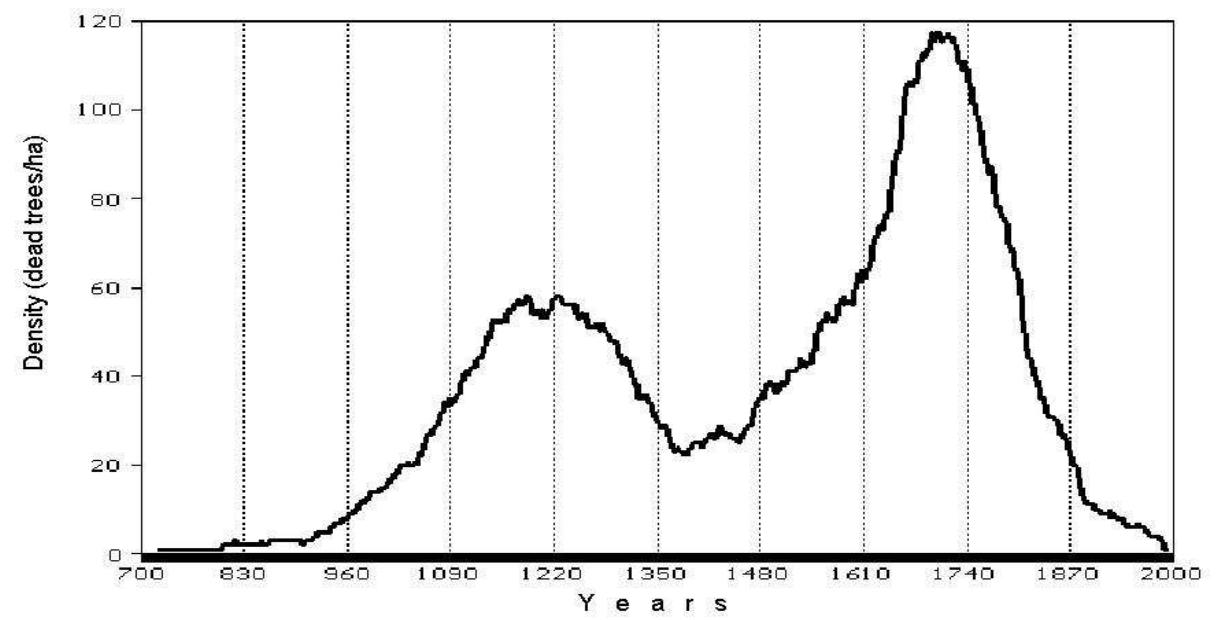

Fig. 8. Changes in stand density within the current tree-line ecotone.

This is based on the earlier observation that the greatest number of undated samples was found in the bottom part of transect, a result of poor preservation. This produces an "empty" area in the bottom right corner on (see Fig. 7). It is assumed, however, that trees would have been growing at these times in this part of transect, as they clearly grew in the upper part of transect. It has therefore been assumed that the life-span of most of the undated wood macrofossils from the lower part of transect can likely be dated from the $9^{\text {th }}$ to $14^{\text {th }}$ centuries. The estimate of tree abundance for the end of the $12^{\text {th }}$ century and the second half of the $13^{\text {th }}$ century is, therefore, increased up to 100-120 trees/ha. 
Abundance began to decline after AD 1280-1300. Minimum tree abundance was reached during the interval 1360-1450. A second period of high tree abundance occurred between 1660 and 1740. The decline began again after 1730. Present-day living trees show that the second minimum of tree abundance was reached at the second half of the $19^{\text {th }}$ century.

The proportional age structure of the trees in these transects has varied greatly during the last millennium (Fig.9). There is clear evidence that two distinct generations of trees appeared, between the $10^{\text {th }}$ to $11^{\text {th }}$ and $16^{\text {th }}$ to $17^{\text {th }}$ centuries. The percentage of total trees represented by these cohorts throughout their life-spans remained appreciable for 300-350 years. Some trees from the second generation are still alive today. The generation that appeared on the boundary between the $13^{\text {th }}$ and $14^{\text {th }}$ centuries was not so numerous. In $200-$ 250 years the proportion of these trees was insignificant. The generation, which appeared in the $18^{\text {th }}$ and $19^{\text {th }}$ centuries, was even smaller. The number of these trees within the total age structure did not exceed $15-20 \%$.

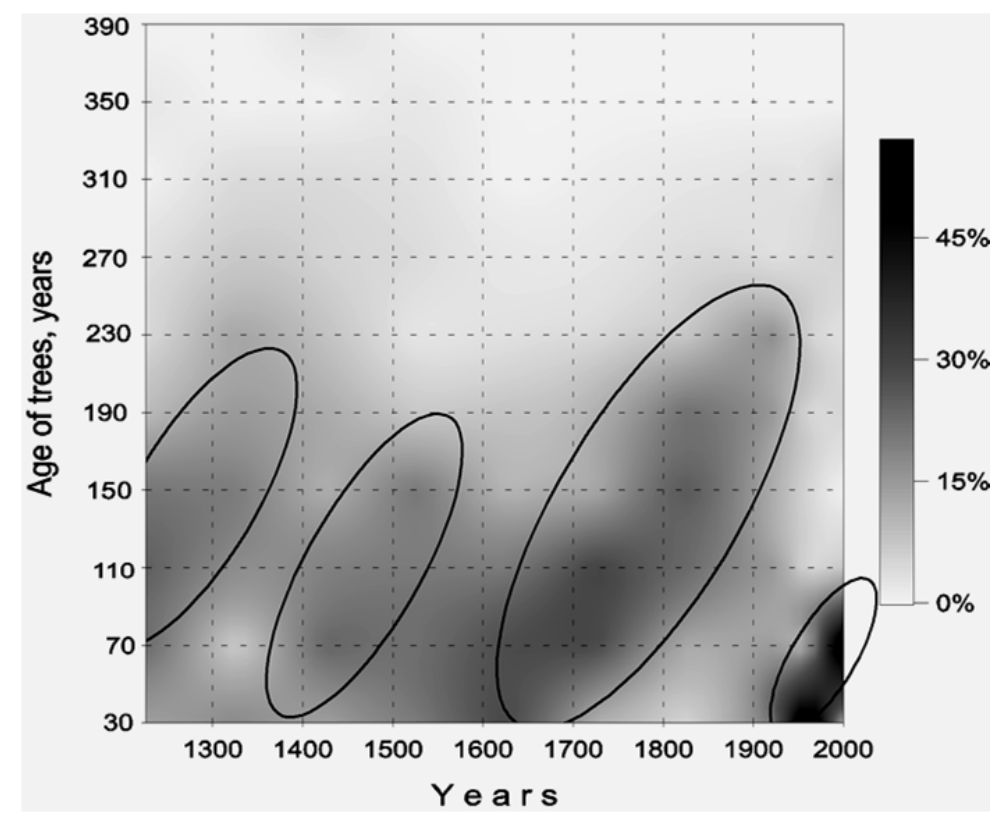

Fig. 9. Changing age structure of tree populations in the current tree-line ecotone. Distinct generations are marked by ellipses.

The analysis of 4 transects within the former tree-line ecotone, now being as a treeless site and 60-80 m above modern one, has shown that the locations of the dead, dated larch trees was more or less uniform because of microrelief (Fig. 10). Peak of abundance is observed from the end of the $11^{\text {th }}$ century to the second half of the $14^{\text {th }}$ century. The large generation in the $18^{\text {th }}$ and $19^{\text {th }}$ centuries did not appear.

On the base of life-span for dead trees (more than 1200 pieces) which grew above current tree-line ecotone the estimation of the most high-altitude position of tree-line for the last 1500 years was received (Fig. 11). The most high-altitude position of tree-line during the medieval climatic optimum was estimated at altitude $400-420 \mathrm{~m}$ a.s.l. This border occupied 
the highest position during $13^{\text {th }}$ and in the beginning of $14^{\text {th }}$ centuries. After that the huge dying off of trees, decrease of sparse tree growth and light forests up to the beginning of $20^{\text {th }}$ century has begun. Intensive decrease of this border and thinning of forest stands occurred in $15^{\text {th }}$ and $16^{\text {th }}$ centuries and especially in $19^{\text {th }}$ century.

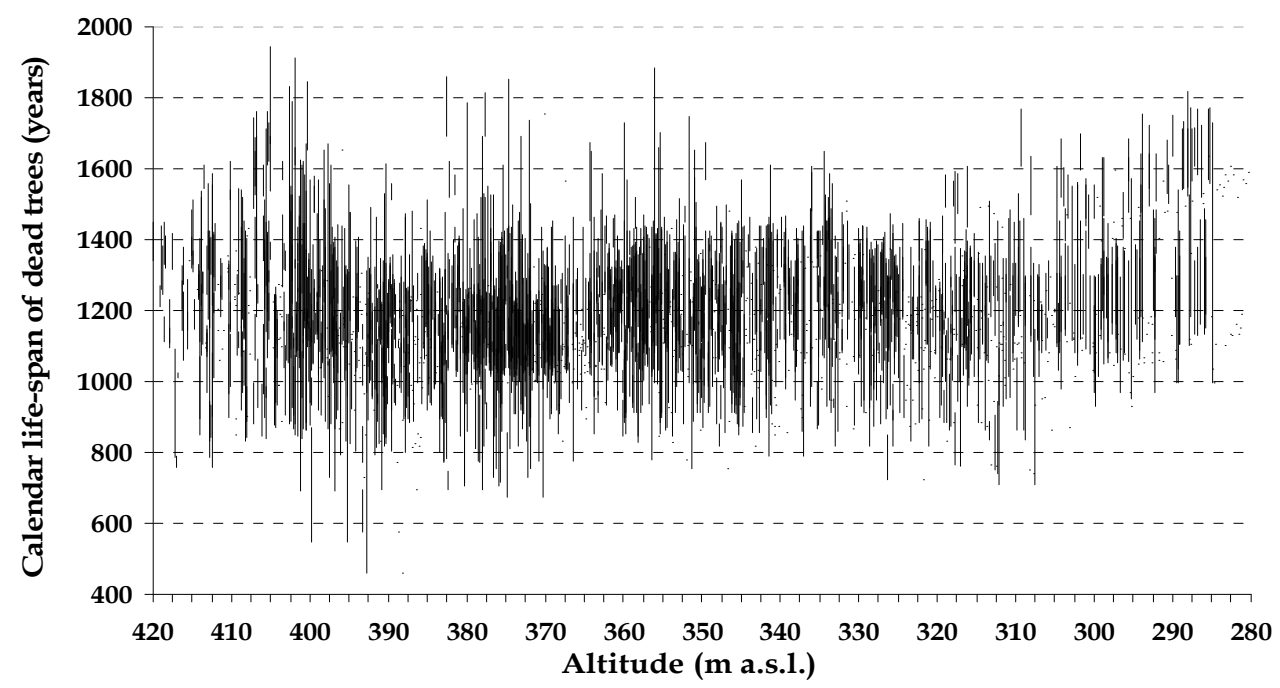

Fig. 10. Location of the dated larch remains along transects and their life-span. Transects laid out $80 \mathrm{~m}$ above current tree-line.

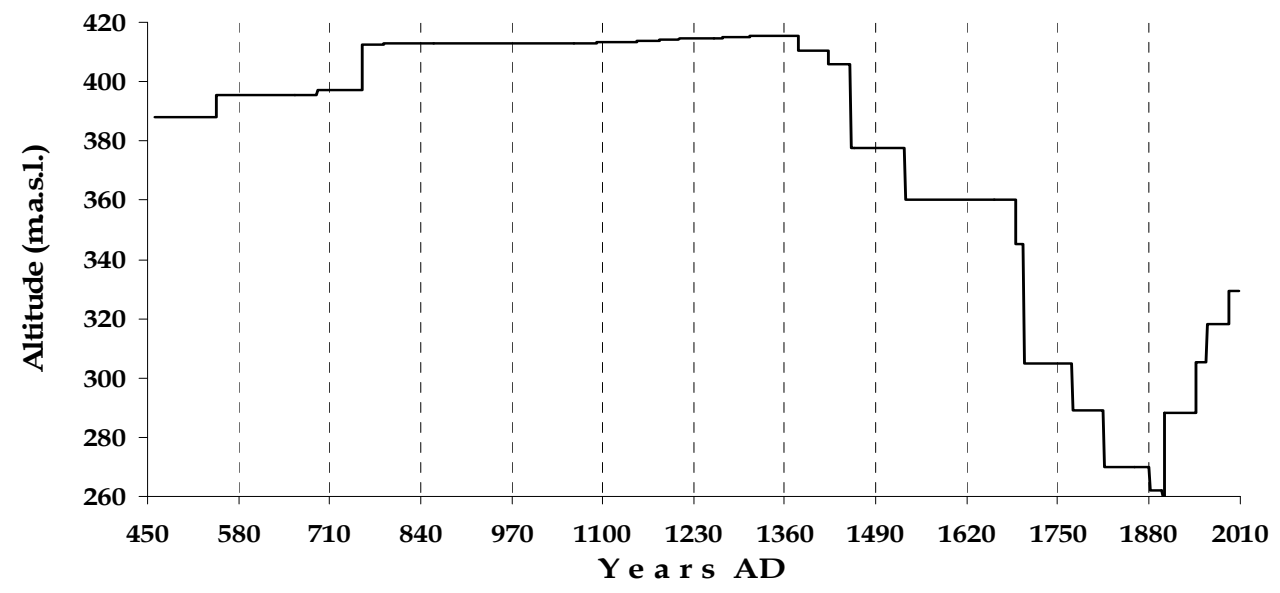

Fig. 11. Shifts of the upper tree-line in the Polar Urals for the last 1500 years.

The estimation of changes in forest stand biomass for the last millennium was received. The long trends of changes in dynamics of productivity are well expressed, which caused by 
century fluctuations of thermal conditions of summer months. It is clearly visible, that trends of biomass changes and tree-ring indexes are the same. It testifies to an oneorientation of these processes. High-altitude position of sparse tree growth, light forests and density of forest stands synchronously changed as well (Fig. 12).

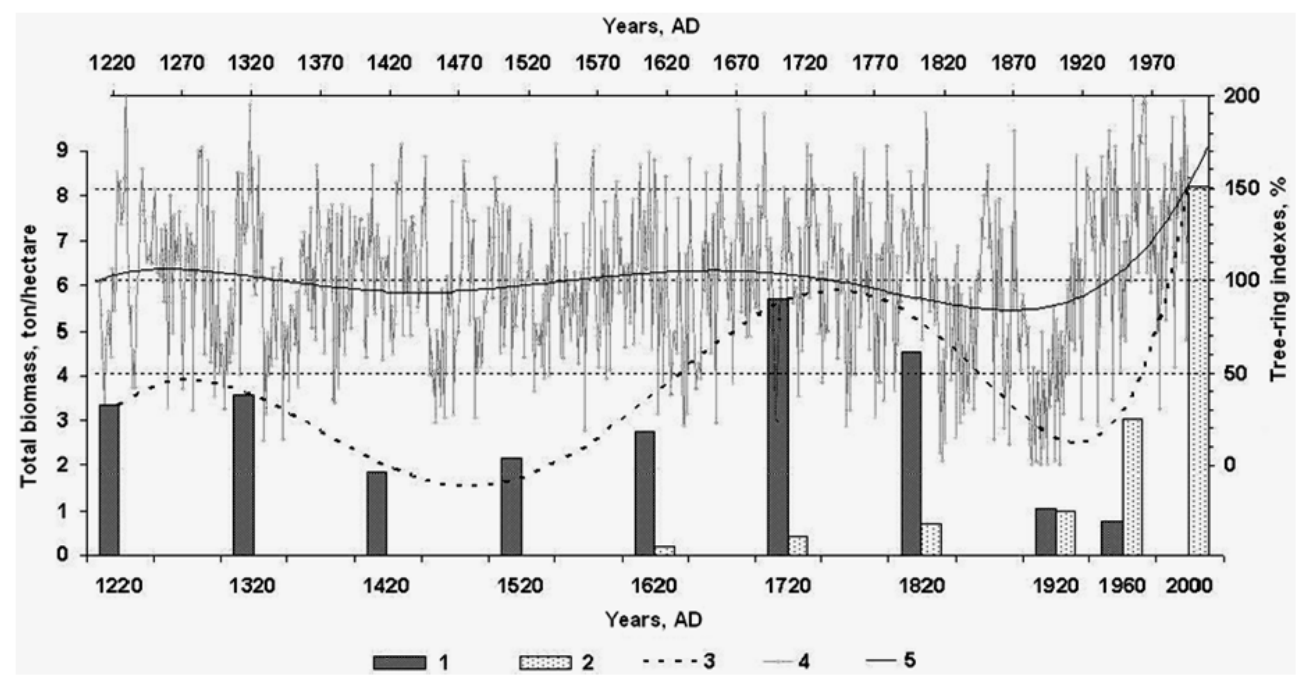

Fig. 12. Open forest's biomass changing in the last 800 years: (1) biomass of dead trees; (2) biomass of living trees; (3) trend of biomass changing; (4) tree-ring indexes; (5) trend of treering indexes.

Previous studies have concluded that increases in tree-line elevation, and associated increases in tree abundance within the transient tree-line ecotone, are associated with extended warm periods (Tranquillini, 1979; Kullman, 1986).

The increase in tree abundance in the upper tree-line ecotone in the Polar Ural Mountains that has been dated to between AD 1150 and 1250 corresponds to a period of relatively warm June-July temperatures, as inferred from Siberian larch ring-width change adjacent to the study area. Early medieval times, from about 1100 to 1250, experienced warming above the long-term mean and relatively stable interannual temperature variability. Reconstructed June-July temperatures generally remained high until the late 1500s, with two major exceptions: the cool periods centered on 1300 and 1460. These times represent two of three periods with the most rapid decreases in temperature observed between adjacent 20-year periods (Graybill \& Shiyatov, 1992). The episode of increasing tree abundance between 1660 and 1740 corresponds to a shorter period, which is dominated by positive temperature anomalies relative to the 1951-1970 mean. Reconstructed interannual temperature variations after 1500 are highest between 1750 and 1769, with a lesser peak occurring again in the late 19 th and early $20^{\text {th }}$ centuries.

The species structure of forest vegetation and climate in the Holocene was reconstructed on the basis of macroscopic plant remnants, botanical analysis of peat, radiocarbon dating (Koshkarova et al., 1999), and palynological, paleocarpological, and paleoentomological analyses of frozen deposits (Panova et al., 2003) in the Polar Ural peatland (Massif Rai-Iz). 
The results showed that the upper forest limit repeatedly migrated upward for 220-400 $\mathrm{m}$ in the periods of warming and retreated during cold periods.

As the vertical gradient of summer air temperature in the Polar Urals is $0.7^{\circ} \mathrm{C} / 100 \mathrm{~m}$, the temperature dependent upper boundary of the zone suitable for tree growth rose by approximately $100 \mathrm{~m}$ (Shiyatov, 2003). On the majority of slopes, however, trees failed to expand up to this potential elevation because of an insufficient seed supply to the tundra areas located in the upper part of the ecotone. As shown previously (Shiyatov, 1966), larch seeds in this region fall in June or July, when the snow cover disappears, and are carried by wind no farther than 40-60 m away from the fertile tree. Hence the spread of seeds up the slope is very slow. That is why many habitats suitable for tree growth have as yet remained vacant. This line of reasoning may also be used to explain more active natural afforestation within the tundra and transformation of sparse stands into closed forests in the lower part of the tree-line ecotone, where microclimatic and soil conditions are more favorable and seed supply is more abundant.

\subsection{Twentieth-century stand dynamics}

\subsubsection{Growth form changes}

The upward expansion of forests was accompanied by significant changes in tree growth forms (Fig. 13). Larches that had been growing in a creeping form since the $15^{\text {th }}$ century started to grow upright at the beginning of the $20^{\text {th }}$ century, with up to 20 stems per tree individual. More than $90 \%$ of the trees emerging after 1950 are single-stem ones.

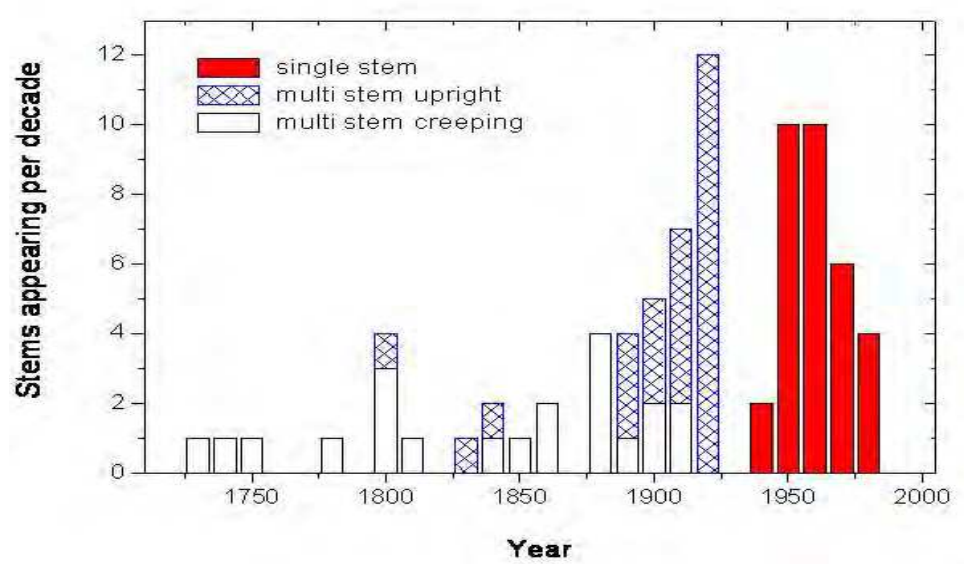

Fig. 13. Growth form changes of larch trees in exposed sites under snowpack by snow abrasion, low temperatures and wind.

The changes of multi-stemmed trees from creeping to vertical growth led to a 2- to 10-fold increase in radial growth of the creeping stems (Fig. 14). We mainly attribute these strong increases in ring width to the higher photosynthetically active needle area from several emerging vertical stems. More favorable climatic conditions might also have contributed to the growth enhancements, but the increases in ring widths of the horizontal stems of multistemmed trees were much greater and more abrupt than the climatic-driven increases in the ring widths of single-stemmed trees. 


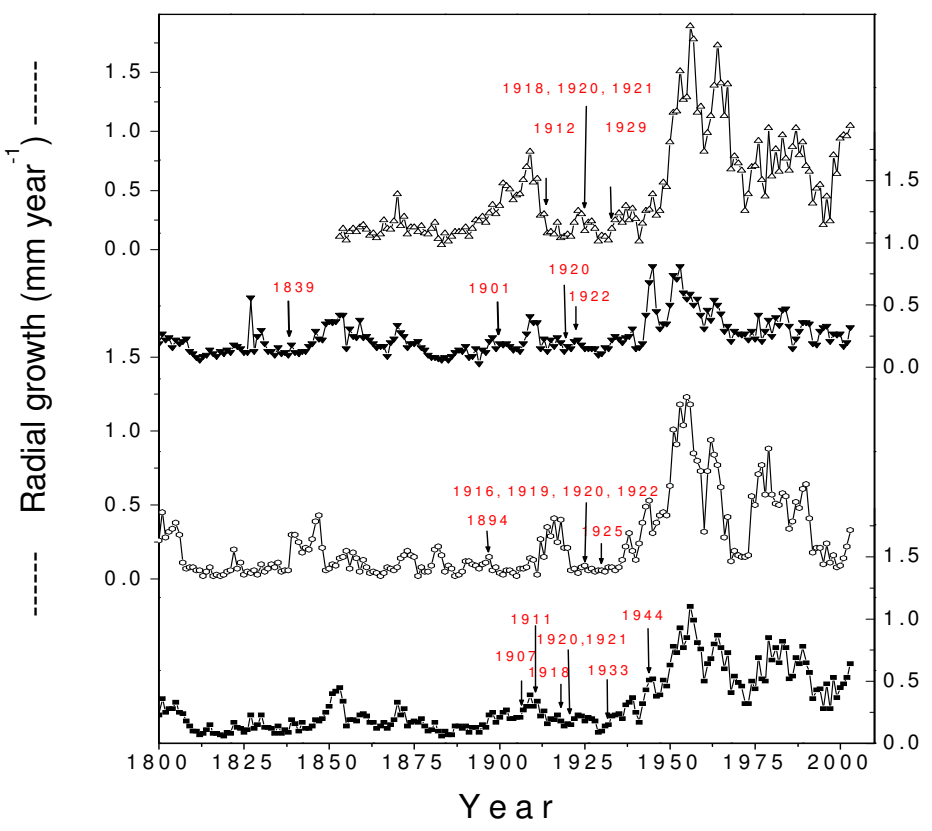

Fig. 14. Tree-ring widths of horizontal stems from multi-stem trees during the last two centuries. The arrows indicate the beginning of upright stem growth.

According to our tree-ring analysis, vertical stems of multi-stemmed larch trees emerged during a relatively short period, i.e. only a few decades (Figs 7 and 8). This contrasts with the behavior of 'mobile', 500-year-old tree islands in the Colorado Front Range, where windward edges are dying back and new stems are emerging over long periods on the leeward side (Marr, 1977; Benedict, 1984). Our age analysis of horizontal and vertical stems indicate that in the Polar Urals vertical growth of multi-stemmed larch is a much more recent phenomenon, and because climatic conditions have apparently been changing rapidly, multi-stemmed trees are very likely only a transitional growth form. Singlestemmed larches are dominating already now $50 \mathrm{~m}$ below current treeline. Therefore, when conditions are becoming slightly more favorable, larch seedlings can succeed as single stems, and they do not first grow in a creeping form before they start to grow upright. As multi-stems are a in transitional growth form, they are indicators for changing growth conditions that can easily be dated using dendrochronological methods.

\subsubsection{Large-scale mapping}

We concentrate our attention on the recent expansion of forest-tundra ecosystems, which began 80-90 years ago in connection with climate warming and moistening. Summer temperature (since 1921) at Salekhard weather station increased by $0.9{ }^{\circ} \mathrm{C}$ and winter temperature by $1.2{ }^{\circ} \mathrm{C}$ in comparison with the first period of observation (1883-1920). It 
means that summer temperature isotherm rose 120-130 $\mathrm{m}$ in altitude. Mean precipitation of summer months is increased from 146 to $178 \mathrm{~mm}$ and of winter months from 67 to $113 \mathrm{~mm}$.

To estimate spatio-temporal changes of forest-tundra ecosystems, which occurred during the 20th century, special attention was given to description and large-scale mapping of forest-tundra ecosystems over the treeline ecotone. To present day the area of 5770 hectares was mapped. Two maps were developed which show the state of stands for the beginning and end of the 20th century (Fig. 15).

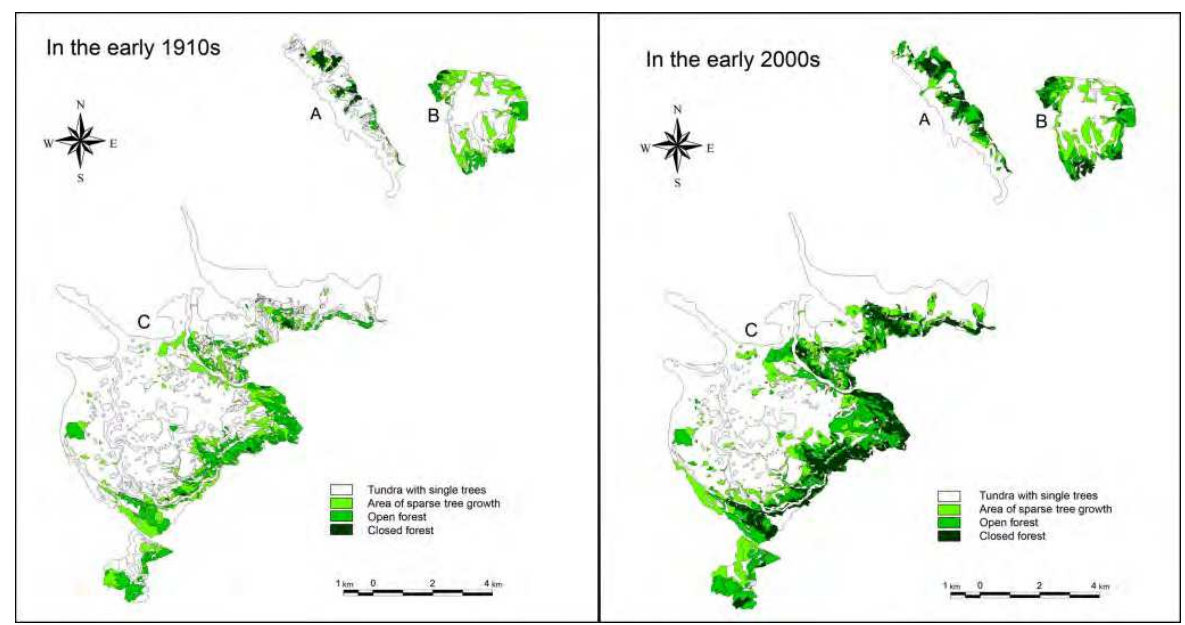

Fig. 15. The spatial distribution of different forest-tundra communities in the ecotone of the upper tree-line in the Polar Urals during 1910-s and 2000-s: (A and C) the area of the Rai-Iz massif and Mts. Chernaya and Malaya Chernaya; (B) the area of Mt. Slantcevaya.

During the last 90 years a significant afforestation of tree-line ecotone has occurred. The area under tundra with individual trees decreased from 4399 to 3306 ha or $25 \%$, the area under sparse growth of trees increased from 662 to 775 ha or $15 \%$, the area under open forests increased from 640 to 1066 ha or $40 \%$. The most impressive changes were seen with closed forests. The area increased from 69 to 623 ha or $89 \%$ as a result of the transformation of sparse growth of trees and open forests into closed forests. The degree afforestation within the tree-line ecotone (including sparse growth of trees, open forests and closed forests) has increased from 1371 ha to 2464 ha or $45 \%$.

Impressive changes have occurred in the structure and productivity of existing stands during the last 90 years. From the beginning of warming an intensive renewal larch and spruce occurred. Most of stands have become much denser and more productive (up to 2-5 times) and many tundra sites located within the treeline ecotone have been afforested. To date young generation of trees is formed, which come to upper wood canopy and occupies dominating position in the majority of stands. This generation is presented basically by single stem form of growing even on powerfully wind sites, while middle-aged generation is presented mainly multi-stem form of growing.

\subsubsection{Repeat landscape photographs}

To date, repeat photographs are made from 1200 points, the majority of which were used for quantitative and qualitative estimation of changes in the tree and shrub vegetation that have 
occurred over the past 30-50 years. During this period of time there was an intensive expansion of tree and shrub vegetation into mountain tundra. These changes occurred under the influence of the modern warming and moistening of climate (Fig. 16-23).

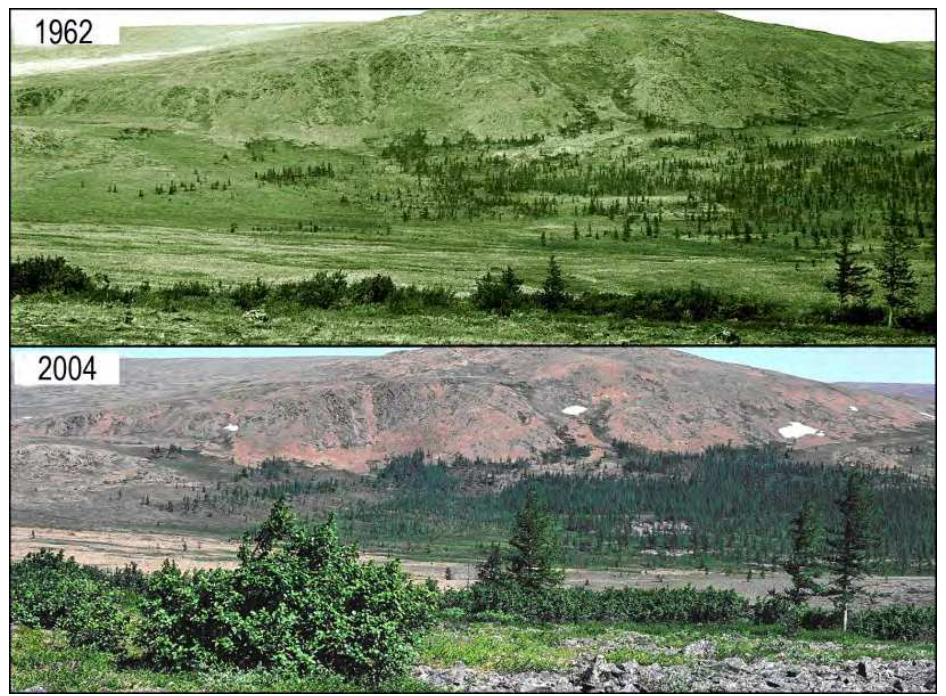

Fig. 16. The western extremity of the stand strip located at the bottom of a southern slope of Rai-Iz massif (66 $50.853^{\prime}$ N, 653․058' E, 295 m a.s.l.).

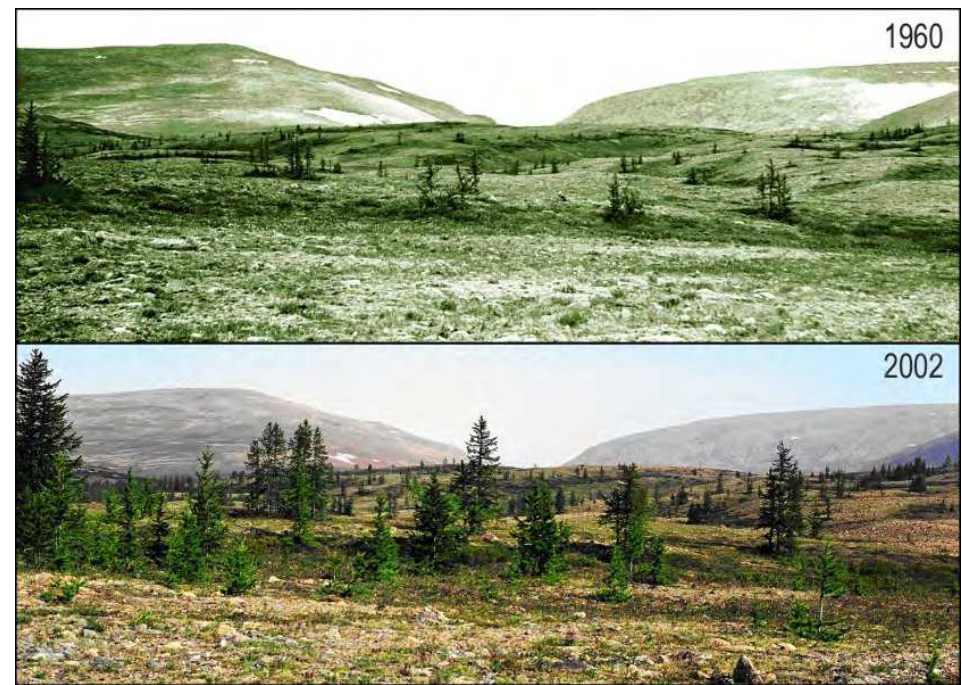

Fig. 17. General view of moraine on the left bank of Kerdomanshor River $\left(66^{\circ} 50.326^{\prime} \mathrm{N}\right.$, $65^{\circ} 34.294^{\prime}$ E, $226 \mathrm{~m}$ a.s.1.). 


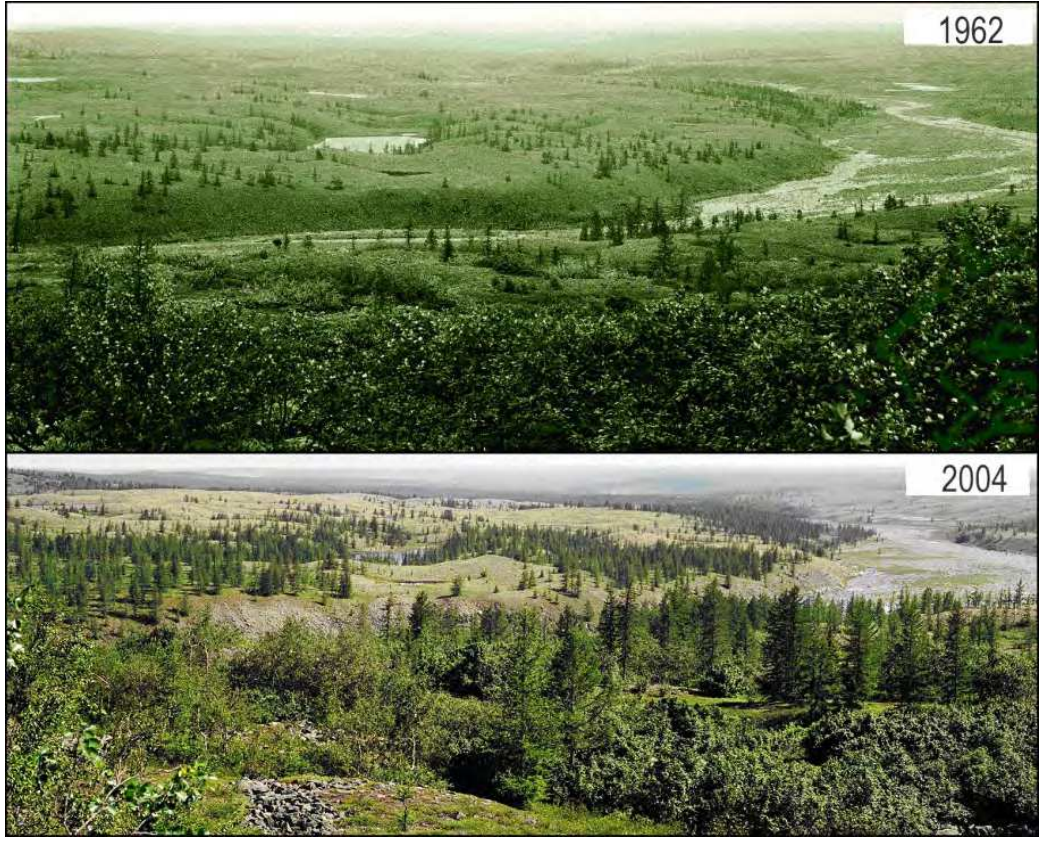

Fig. 18. The bottom of eastern slope of Malaya Chernaya Mountain $\left(66^{\circ} 50.751^{\prime} \mathrm{N}, 65^{\circ} 32.770^{\prime}\right.$ E, $286 \mathrm{~m}$ a.s.1.).

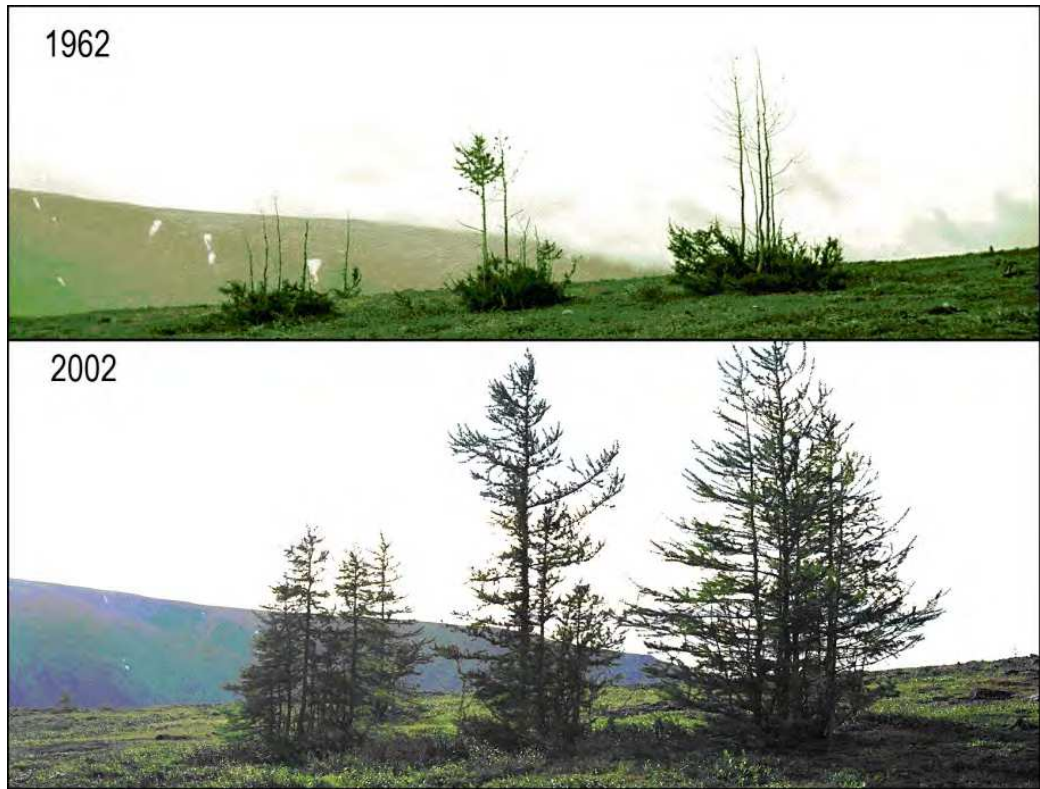

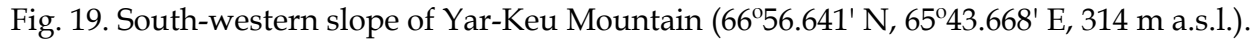




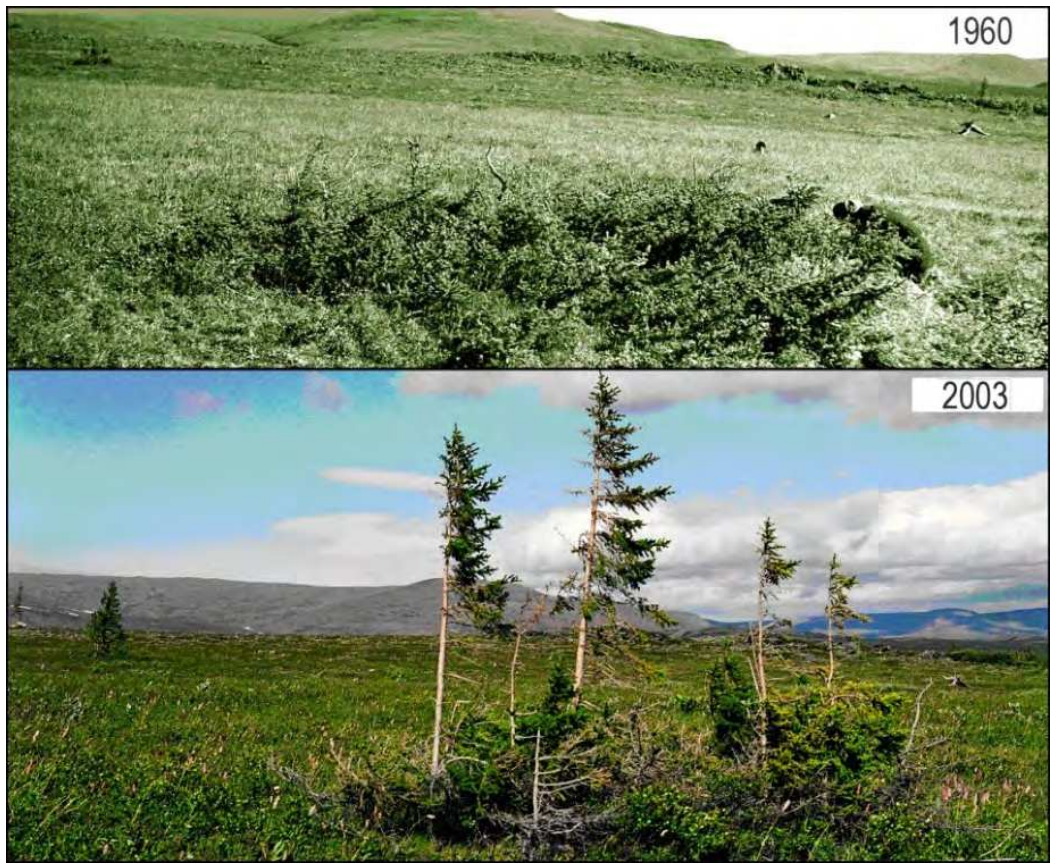

Fig. 20. Spruce growth form changes from creeping to multi-stem growth $\left(66^{\circ} 48.923^{~} \mathrm{~N}\right.$, 653․ $310^{\prime} \mathrm{E}, 251 \mathrm{~m}$ a.s.l.).

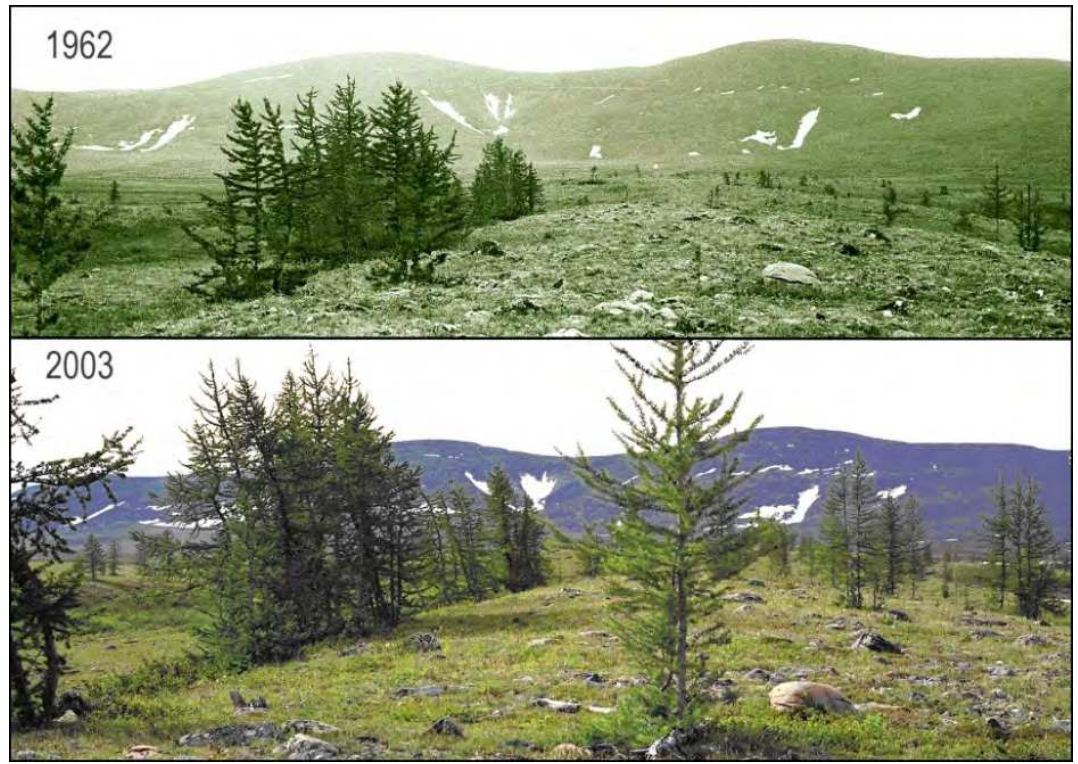

Fig. 21. The top part of a lateral moraine $\left(66^{\circ} 47.477^{\prime} \mathrm{N}, 65^{\circ} 30.778^{\prime} \mathrm{E}, 267 \mathrm{~m}\right.$ a.s.l.). 


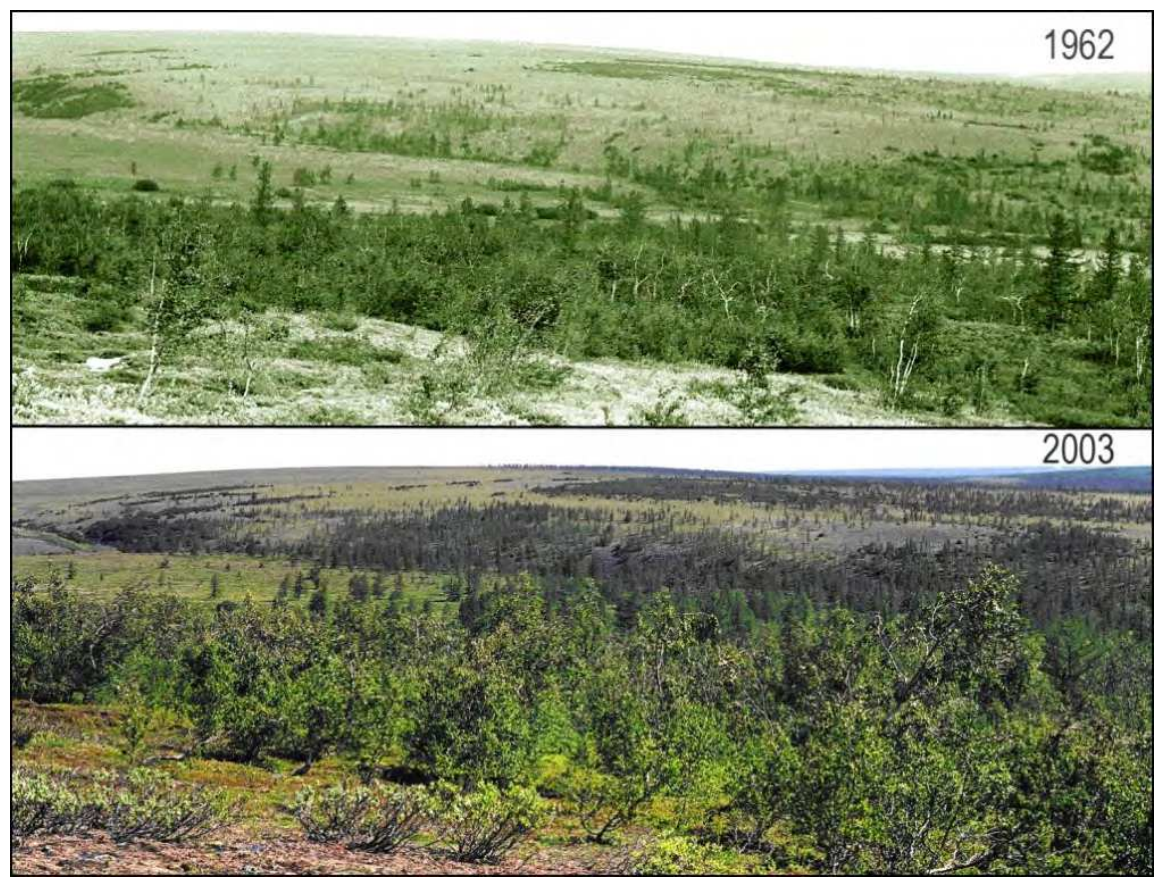

Fig. 22. Southern slope of a hill of $429 \mathrm{~m}$. Small river Orehyogan below $\left(66^{\circ} 47.338^{\prime} \mathrm{N}\right.$, $65^{\circ} 23.601^{\prime} \mathrm{E}, 287 \mathrm{~m}$ a.s.1.).

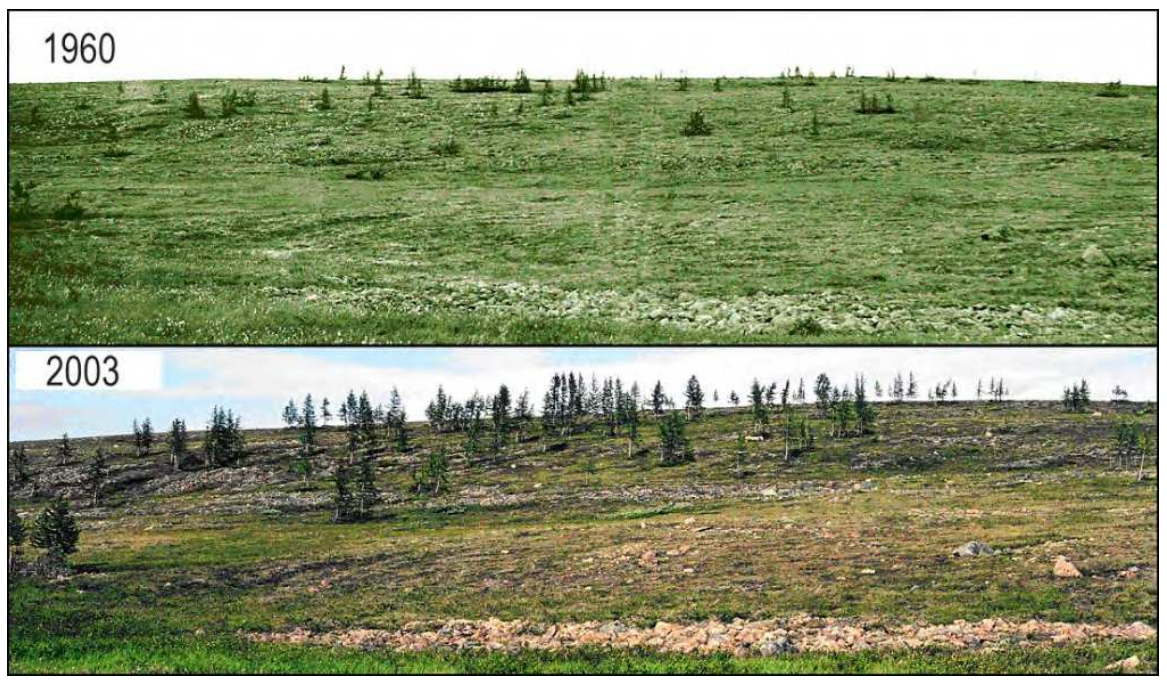

Fig. 23. The uppermost light forest growing on a southern slope of height of $312.8 \mathrm{~m}$ $\left(66^{\circ} 49.060^{\prime} \mathrm{N}, 65^{\circ} 32.262^{\prime} \mathrm{E}, 267 \mathrm{~m}\right.$ a.s.l.). 


\section{Conclusion}

The earlier analysis (Shiyatov 1993, Fig. 1) showed a similar conclusion based on 209 macro fossils and 16 living trees. A maximum tree abundance being reached in the middle of the $13^{\text {th }}$ century. In the first half of the $15^{\text {th }}$ century a deterioration of forest cover came to an end. In the $16^{\text {th }}$ century and first half of the $17^{\text {th }}$ century tree growing conditions were again more favourable, and in the second half of the $16^{\text {th }}$ century another decline of the open larch forests ceased. In the second half of the $18^{\text {th }}$ century all trees growing on the transect died. In the $19^{\text {th }}$ century not a single living tree stood on the transect. The first larch seedlings reappeared at the beginning of the 20th century. These two independent analyses are, therefore, mutually supportive.

The upper boundary of open forests has markedly shifted both on slopes exposed in winter to strong westerly winds and in the areas where summer temperatures are the main limiting factors. This is evidence that the pattern of winds and the temperature conditions have become more favorable for the growth of trees over the past 90 years. The growing period begins earlier, and its duration has increased. This allows young larch shoots to complete the cycle of their growth and development and to prepare themselves for wintering under severe conditions. Before the recent climate warming, larch in windswept conditions with little snow was represented only by prostrate growth form. To date, prostrate plants have transformed into multi-stemmed trees up to 5-6 $\mathrm{m}$ high and young trees aged up to 50-60 years are mainly single-stemmed.

These data on the magnitude of altitudinal and horizontal shifts in the upper boundaries of open and closed forests in the Polar Urals confirm our previous findings concerning the expansion of tree vegetation to higher elevations due to climate warming and increasing humidity in the $20^{\text {th }}$ century (Shiyatov et al., 2007). According to data from the Salekhard weather station the recent mean air summer temperature was $0.9^{\circ} \mathrm{C}$ higher and winter was $1.2^{\circ} \mathrm{C}$ higher than between 1883 and 1919; and the amount of precipitation also increased by $32 \mathrm{~mm}$ in summer and by $46 \mathrm{~mm}$ in winter. As the elevational lapse rate of summer air temperatures in the Polar Urals is $0.7^{\circ} \mathrm{C}$, the climate-dependent upper boundary of the zone suitable for tree growth could ascend approximately $100 \mathrm{~m}$. This value is almost three times greater than the actual altitudinal shift of the upper boundary of open and closed forests. In other words, tree vegetation has not yet expanded to the climatic limit because of insufficient supply of larch seeds to tundra areas in the upper part of the treeline ecotone, although it is already close to this limit on some slopes.

Thus, the analysis of vertical and horizontal shifts in the upper boundaries of open and closed forests on the eastern macroslope of the Polar Urals provides evidence for widespread and active expansion of tree vegetation to higher elevations over the past 90 years, which is apparently explained by favorable changes in climatic conditions.

The improvement of climatic conditions in the first half of the $20^{\text {th }}$ century resulted in the development of multi-stemmed life forms in Siberian larch through the formation of vertical stems from its prostrate and stem-shrub life forms. The active growth of multi-stemmed trees and consequent increase in their size during the $20^{\text {th }}$ century resulted in increasing competition for light and nutrients between stems and crowns within the same clone. As a consequence, some stems dried out. Data on the time of tree emergence obtained in this study agree with the known fact that active forest regeneration takes place mainly in relatively warm climatic periods with higher humidity. 
Historic photographs and tree age structure analyses indicate that remote areas of the foresttundra ecotone in the Polar Urals have changed significantly during the $20^{\text {th }}$ century. The distribution of Siberian larch has been shifting upwards by $20-60 \mathrm{~m}$ in altitude, and today young larch trees are growing in formerly treeless tundra. Since 1900, growth forms of larch have started to change from creeping growth that prevailed over centuries to upright growth as multi-stemmed trees. At the same time, single-stemmed trees have commenced to establish. At present, the single-stemmed larches are dominating the forest $50 \mathrm{~m}$ below the species line. The expanding close forest led to an increase of biomass by $40-75 \mathrm{t} \mathrm{ha}^{-1}$ and a carbon sequestration of approximately $20-40 \mathrm{gCm}^{-2} \mathrm{yr}^{-1}$ during the last century, which is, however, small compared with temperate forests. The forest expansion and change in growth forms coincided with a significant warming in summer and a doubling of winter precipitation, thus drastically changing snow conditions. In summary, our study shows that the ongoing climatic changes are altering the composition, structure, and growth forms of Siberian larch in undisturbed tree-line ecotones of the Polar Urals.

The absence of evidence of forest fires or other catastrophic phenomena in the study area and the similar absence of any evidence of significant human influence on the open larch forests strongly attest to the probability that forest dynamics in the region are the result of climatic changes alone. If the reconstruction of these tree dynamics describes the changing influence of climate in the Polar Urals Mountains during the period represented in this study, then the hypothesis that the expansion of forest is always associated with warm temperatures is generally supported by these results.

\section{Acknowledgments}

This research was financially supported by the Russian Foundation for Basic Research (Grants: 04-04-48687, 07-04-00847, 08-04-00208, 10-04-01484, 11-04-00623), in part by INTAS project 01-0052 and projects ГК 02.740.11.0279, 09-П-4-1004, 09-T-4-1005. We thank Lyudmila Gorlanova and Natalia Ukhabina for laboratory assistance and students for field assistance.

\section{References}

Andreev, V.N.; Igoshina, K.N. \& Leskov, A.I. (1935). Reindeer pastures and vegetation cover in the Polar Urals. Soviet Deer Farming, No.5, pp. 171-406. [In Russian].

Becker, A. \& Bugmann, H. (2001). Global Change and Mountain Regions: The Mountain Research Initiative. IGBP Report 49. IGBP Secretariat, Stockholm, Sweden.

Benedict JB (1984) Rates of tree-island migration, Colorado Rocky Mountains, USA. Ecology, No. 65, pp. 820-823. ISSN: 0012-9658

Briffa, K.R. \& Jones, P.D. (1993). Global surface air temperature variations during the twentieth century. Part 2. Implications for large-scale high-frequency palaeoclimatic studies. The Holocene, Vol.3, pp. 77-88, ISSN: 0959-6836

Briffa, K.R.; Jones, P.D.; Schweingruber, F.H.; Shiyatov, S.G. \& Cook, E.R. (1995). Unusual twentieth-century summer warmth in the 1000-year temperature record from Siberia. Nature, Vol.376, pp. 156-159, ISSN: 0028-0836

Chapin, F.S. III.; McGuire, A.D.; Randerson, J. et al. (2000). Arctic and boreal ecosystems of western North America as components of the climate system. Global Change Biology, 6, 211-223. ISSN: 1365-2486 
Chapin, F.S. III.; Sturm, M.; Serreze, M.S. et al. (2005). Role of landsurface changes in arctic summer warming. Science, Vol.310, pp. 657-660. ISSN: 0869-7078

D’Arrigo, R.D.; Kaufmann, R.K.; Davi, N.; Jacobi, G.C.; Laskowski, Ch.; Myreni, R.B. \& Cherubini, P. (2004). Thresholds for warming-induced growth induced growth decline at elevational tree line in the Yukon Territory, Canada. Global Biochemical Cycles, 18, GB3021, doi: 10.1029/2004GB002249.

Devi, N.; Hagedorn, F.; Moiseev, P.A.; Bugmann, H.; Shiyatov, S.; Mazepa, V. \& Rigling, A. (2008). Expanding forests and changing growth forms of Siberian larch at the Polar Urals treeline during the 20th century. Global Change Biology, Vol.14, pp. 1581-1591. ISSN: 1365-2486

Esper, J. \& Schweingruber, F.H. (2004). Large-scale treeline changes recorded in Siberia. Geophysical Research Letters, 31, L06202, doi: 10.1029/2003GL019178.

Gorchakovskiy, P.L. \& Shiyatov, S.G. (1985). Phytoindication of the Environmental Conditions and Natural Processes in the Alpine Terrain. Nauka, Moscow. [in Russian].

Gorodkov, B.N. (1926). The Polar Urals in the watershed of the Sob River. In Proc. Bot. Mus. USSR Acad. Sci. Vol.19, pp. 1-74. [In Russian].

Goroshkevich, S.N. \& Kustova, E.A. (2002). Morphogenesis of the creeping life form of Siberian cedar at the upper limit of proliferation in West Sayan Mountains. Russian Journal of Ecology, No.4, pp. 243-249. ISSN: 1067-4136

Graybill, D.A., \& Shiyatov, S.G. (1992). Dendroclimatic evidence from the northern Soviet Union. In Climate since A.D. 1500, R.S. Bradley \& P.D. Jones, (Ed.), Routledge, London. pp. 393-414. ISBN: 0-415-07593-9.

Holmes, R.L. (1995). Dendrochronological Program Library [computer program]. Laboratory of Tree-Ring Research, the University of Arizona, Tucson, Ariz.

Holtmeier, F-K. (2003). Mountain Timberlines. Ecology, Patchiness, and Dynamics. Kluwer, Dordrecht. ISBN: 1-4020-1356-6

IPCC. (2007). Climate Change 2007: The Physical Science Basis. Contribution of Working Group I to the Fourth Assessment Report of the Intergovernmental Panel on Climate Change. In: Solomon, S., Qin, D., Manning, M., Chen, Z., Marquis, M., Averyt, K.B., Tignor, M., Miller, H.L. (Eds.). Cambridge University Press, Cambridge, United Kingdom and New York, 996 pp.

Jackson, S.T.; Overpeck, J.T.; Thompson, W.III.; Sharen, E.K. \& Katherine, H.A. (1997). Mapped plant-macrofossil and pollen records of late quaternary vegetation change in Eastern North America. Quaternary Science Reviews, Vol.16, No.1, pp. 1-70. ISSN: 0277-3791

Kelly, P.M.; Jones, P.D.; Sear, C.B.; Cherry, B.S.G. \& Tavakol R.K. (1982). Variations in surface air temperature: part 2. Arctic regions. 1881-1980. Monthly Weather Review, No.110, pp. 71-82. ISSN: 0027-0644

Kharuk, V.I.; Shiyatov, S.G.; Kashishke, E.; Fedotova, E.V.; Naurzbaev, M.M. (2002). Foresttundra ecotone response to climate change. In: Problems of ecological monitoring and ecosystem modeling. Vol. XVIII, Sankt-Petersburg: Gidrometeoizdat, pp. 234-260. ISBN 5-286-00655-8

Kittel, T.G.F.; Steffen, W.L. \& Chapin, F.S. (2000). Global and regional modelling of arcticboreal vegetation distribution and its sensitivity to altered forces. Global Change Biology, No.6, pp. 1-18. ISSN: 1365-2486 
Körner, Ch. (1999). Alpine plant life. Springer-Verlag, Berlin.

Kobak, K.I. (1988). Biotic components of carbon circle. Gidrometeoizdat, Leningrad. [In Russian].

Koshkarova, V.L., Karpenko, L.V., \& Orlova, L.A. (1999). The Holocene dynamics of vegetation and the upper forest limit in the Polar Urals. Rus. J. Ecol., No.30, pp. 102-106. ISSN: 1067-4136

Kullman, L. (1986). Late Holocene reproductional patterns of Pinus sylvestris and Picea abies at the forest limit in central Sweden. Can. J. Bot. No.64, pp. 1682-1690. ISSN: 0008-4026.

Kullman, L. (1990). Dynamics of altitudinal tree-limits in Sweden: a review. Nor. Geogr. Tidsskr. B, No.44, pp. 103-116.

Kullman, L. (2002). Rapid recent range-margin rise of tree and shrub species in the Swedish Scandes. Journal of Ecology, No.90, pp. 68-77. ISSN: 1365-2745

Lloyd, A.H. (1997). Response of tree-line populations of foxtail pine (Pinus balfouriana) to climate variation over the last 1000 years. Can. J. For. Res. No.27, pp. 936-942. ISSN: 0045-5067

Lloyd, A.H. (2005). Ecological histories from Alaskan tree lines provide insight into future change. Ecology, No.86, pp. 1687-1695. ISSN: 0012-9658

Lloyd, A.H., \& Graumlich, L.J. (1997). Holocene dynamics of treeline forests in the Sierra Neveda. Ecology, No.78, pp. 1199-1210. ISSN: 0012-9658

Marr, J.W. (1977). The development and movement of tree islands near the upper limit on tree growth in the Southern Rocky Mountains. Ecology, No.58, pp. 1159-1164. ISSN: 0012-9658

Martin, Yu.L. (1970). Lichenometric indication of time of rock outcrop's formation. Russ. J. Ecol. No.5, pp. 16-24. [In Russian].

Mazepa, V.S. (2005). Stand density in the last millennium at the upper timberline ecotone in the Polar Ural Mountains. Canadian Journal of Forest Research, Vol.35, pp. 2082-2091. ISSN: 0045-5067

Mazepa V.S. \& Devi N.M. (2007). Development of multi-stemmed life forms of Siberian larch as an indicator of climate change in the timberline ecotone of the Polar Urals. Russian Journal of Ecology, Vol.38, No.6, pp. 440-443, ISSN: 1067-4136

Miller, G.H.; Alley, R.B.; Brigham-Grette, J.; Fitzpatrick, J.J.; Polyak, L.; Serreze, M.C. \& White, J.W.C. (2010). Arctic amplification: can the past constrain the future? Quaternary Science Reviews, Vol.29, pp. 1779-1790. ISSN: 0277-3791

Moiseev, P.A. \& Shiyatov, S.G. (2003). Vegetation dynamics at the treeline ecotone in the Ural Highlands, Russia. Ecological Studies, No.167, pp. 423-435. ISSN: 0070-8356

Myneni, R.B.; Keeling, C.D.; Tucker, C.J.; Ascrar, G. \& Nemani, R.R. (1997). Increased plant growth in the northern high latitudes from 1981 to 1991. Nature, No.386, pp. 698702. ISSN: 0028-0836

Panova, N.K., Jankovska, V., Korona, O.M., \& Zinov'ev, E.V. (2003). The Holocene dynamics of vegetation and ecological conditions in the Polar Urals. Rus. J. Ecol. No.34, pp. 219-230. ISSN: 1067-4136.

Paulsen, J. Weber, U.M. \& Körner, C. (2000). Tree growth near treeline: abrupt or gradual reduction with altitude? Arctic, Antarctic, and Alpine Research, No.32, pp. 14-20. 
Pereg, D. \& Payette, S. (1998). Development of black spruce growth forms at tree-line. Plant Ecology, No.138, pp. 137-147. ISSN: 0065-2113

Shiyatov, S.G. (1965). Age structure and generation of larch light forests in the treeline ecotone in the $\mathrm{Ob}$ river basin (Polar Urals). In: Proceedings of the Institute of Biology, Ural Division of the Academy of Sciences of the USSR: Geography and Dynamics of Plant Community. Sverdlovsk, No.42, pp. 81-96. [In Russian].

Shiyatov, S.G. (1966). Time of dispersion of Siberian larch seeds in the north-western part of its areal and role of that factor in mutual relation between forest and tundra. In Problems of physiology and geobotany. Publication of the Sverdlovsk Branch of the All-Union Botanical Society, No.4. pp. 109-113. [In Russian.]

Shiyatov, S.G. (1986). Dendrochronology of treeline in the Urals. Nauka Publishers, Moscow. (In Russian).

Shiyatov, S.G. (1993). The upper timberline dynamics during the last 1100 years in the Polar Urals Mountains. Eur. Palaeoclim. Man, No.4, pp. 195-203.

Shiyatov, S.G. (2003). Rates of change in the upper tree-line ecotone in the Polar Ural mountains. Pages News, No.11, pp. 8-10. ISSN: 1563-0803

Shiyatov, S.G. (2009). Dynamics of Wood and Shrub Vegetation in the Polar Ural Mountains under the Modern Climate Change. UB RAS. ISBN: 978-5-7691-2035-0, Ekaterinburg. [in Russian].

Shiyatov, S.G. \& Mazepa, V.S. (2007). Climatogenic dynamics of forest-tundra vegetation at the Polar Urals. Lesovedenie, No.6, pp. 37-48. ISSN: 0024-1148 [in Russian].

Shiyatov, S.G.; Terent'ev, M.M., Fomin, V.V. \& Zimmermann N.E. (2007). Altitudinal and Horizontal Shifts of the Upper Boundaries of Open and Closed Forests in the Polar Urals in the 20th Century. Russian Journal of Ecology, Vol.38, pp. 223-227. ISSN: 1067-4136

Shvartsman, Y.G.; Barzut, V.M.; Vidyakina, S.V. \& Iglovsky, S.A. (1999). Climate variations and dynamic ecosystems of the Arkhangelsk region. Chemosphere. Global Change Science, No.1, pp. 417-428. ISSN: 1465-9972

Silapaswan, C.S., Verbyla, D.L. \& McGuire, A.D. (2001). Land cover change on the Seward Peninsula: The use of remote sensing to evaluate the potential influences of climate warming on historical vegetation dynamics. Canadian Journal of Remote Sensing, No.27, pp. 542-554. ISSN: 0703-8992

Sochava, V.B. (1927). Botanical essay of the Polar Ural forests from the Nelkja River to the Kulga River. In: Proc. Bot. Mus. USSR Acad. Sci. No.21, pp. 1-71. [In Russian].

Solomina, O.N. (1999). Mountain glaciation of northern Eurasia in the Holocene. Scientific World, Moscow. [In Russian].

Sukachev, V.N. (1922). Climate and vegetation changes during the post-Tertiary time in the Siberian north. Meteorol. Vestn. No.1-4, pp. 25-43. [In Russian].

Sturm, M.; Schimel, J.; Michaelson, G. et al. (2005). Winter biological processes could help convert Arctic tundra to shrubland. BioScience, No.55, pp.17-26. ISSN: 0006-3568

Tranquillini, W. (1979). Physiological ecology of the alpine timberline. Springer-Verlag, Berlin. 
Vaganov, E.A., Shiyatov, S.G. \& Mazepa V.S. (1996). Dendroclimatic Study in Ural-Siberian Subarctic. Nauka, Siberian Publishing Firm RAS, ISBN: 5-02-031185-5, Novosibirsk. [In Russian].

Vaganov, E.A.; Hughes, M.K.; Kirdyanov, A.V.; Schweingruber, F.H. \& Silkin, P.P. (1999). Influence of snowfall and melt timing on tree growth in subarctic Eurasia. Nature, 400, 149-151. ISSN: 0028-0836

Weisberg, P.J. \& Baker, W.L. (1995). Spatial variation in tree seedling and krummholz growth in the forest - tundra ecotone of Rocky Mountain National Park, Colorado, U.S.A. Arctic and Alpine Research, No.27, pp. 116-129. ISSN: 1523-0430 


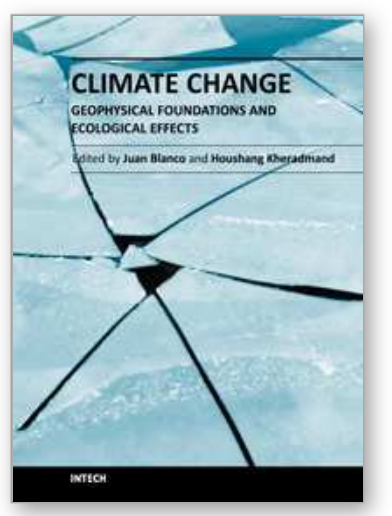

\author{
Climate Change - Geophysical Foundations and Ecological Effects \\ Edited by Dr Juan Blanco
}

ISBN 978-953-307-419-1

Hard cover, 520 pages

Publisher InTech

Published online 12, September, 2011

Published in print edition September, 2011

This book offers an interdisciplinary view of the biophysical issues related to climate change. Climate change is a phenomenon by which the long-term averages of weather events (i.e. temperature, precipitation, wind speed, etc.) that define the climate of a region are not constant but change over time. There have been a series of past periods of climatic change, registered in historical or paleoecological records. In the first section of this book, a series of state-of-the-art research projects explore the biophysical causes for climate change and the techniques currently being used and developed for its detection in several regions of the world. The second section of the book explores the effects that have been reported already on the flora and fauna in different ecosystems around the globe. Among them, the ecosystems and landscapes in arctic and alpine regions are expected to be among the most affected by the change in climate, as they will suffer the more intense changes. The final section of this book explores in detail those issues.

\title{
How to reference
}

In order to correctly reference this scholarly work, feel free to copy and paste the following:

Valeriy Mazepa, Stepan Shiyatov and Nadezhda Devi (2011). Climate-Driven Change of the Stand Age Structure in the Polar Ural Mountains, Climate Change - Geophysical Foundations and Ecological Effects, Dr Juan Blanco (Ed.), ISBN: 978-953-307-419-1, InTech, Available from:

http://www.intechopen.com/books/climate-change-geophysical-foundations-and-ecological-effects/climatedriven-change-of-the-stand-age-structure-in-the-polar-ural-mountains

\section{INTECH}

open science | open minds

\section{InTech Europe}

University Campus STeP Ri

Slavka Krautzeka 83/A

51000 Rijeka, Croatia

Phone: +385 (51) 770447

Fax: +385 (51) 686166

www.intechopen.com

\section{InTech China}

Unit 405, Office Block, Hotel Equatorial Shanghai

No.65, Yan An Road (West), Shanghai, 200040, China

中国上海市延安西路65号上海国际贵都大饭店办公楼405单元

Phone: +86-21-62489820

Fax: $+86-21-62489821$ 
(C) 2011 The Author(s). Licensee IntechOpen. This chapter is distributed under the terms of the Creative Commons Attribution-NonCommercialShareAlike-3.0 License, which permits use, distribution and reproduction for non-commercial purposes, provided the original is properly cited and derivative works building on this content are distributed under the same license. 